\title{
Embryogenesis in phoronids
}

\section{E.N. Temereva, V.V. Malakhov}

\author{
Department of Invertebrate Zoology, Biological Faculty, Moscow State University, Moscow \\ 119992, Russia. \\ e-mail: temereva@mail.ru
}

ABSTRACT: The Phoronida is a phylum of marine animals whose position in the Bilateria has radically changed as a result of recent molecular phylogenetic analysis. Although molecular data have confirmed the position of phoronids among typical Trochozoa, supporting data from comparative embryology and morphology are lacking. This paper reviews the available literature and also provides original results concerning the early embryonic and larval development of phoronids. Phoronid egg cleavage can be regarded as transitory between a typical radial and typical spiral pattern. The presence of oblique furrows in early phoronid development should not be interpreted to mean that phoronid cleavage is typically radial. At the same time, phoronids lack a specific mosaic of blastomeres, whose presence is characteristic of true spiral development. Phoronids also lack trochoblasts, rosettes, and cross cells. Nondeterministic cleavage with an oblique position of furrows allows the blastula to form at the 16-cell stage, which is very important for species with holopelagic development. In phoronid species that brood, a brick-like embryo appears as a result of early egg development. In phoronids, there are two distinctive sources of coelomic mesoderm: anterior and posterior. Both sources are multicellular and originate from the anterior wall of the archenteron (the anterior mesoderm) or by entherocoely (the posterior mesoderm). Organogenesis starts in the later gastrula. The ectoblast gives rise to the epidermis, ciliated bands, nervous system, excretory system, and some parts of digestive tract (esophagus and proctodaeum). The ultrastructure of the epidermis differs depending on body part. The activity of ciliated bands in phoronid larvae combines features of the Protostomia and Deuterostomia. In actinotrocha, the preoral ciliated band functions as it does in protostomian larvae (the preoral ciliated band beats from anterior to posterior), whereas the postoral ciliated band functions as it does in deuterostomian larvae (the postoral ciliated band beats from anterior to posterior). The first neurons are serotonergic; they appear in the epidermis of the apical plate. In the young larva of Phoronopsis harmeri, the serotonergic nervous system consists of apical ganglion, which contains a U-shaped field of monopolar perikarya, and two groups of bipolar (or multipolar) perikarya; the tentacular neurite bundle, which runs dorsally from the left and right groups of bipolar (or multipolar) perikarya; two nerve rings of the telotroch; the oral nerve ring; and the nervous net around the proctodaeum and pyloric sphincter. In the early larva, serotonergic perikarya originate along the edge of the preoral lobe and then disappear. At this stage, the perikarya on the ventral body side form the ventral nerve cord and then also disappear. The FMRFamidergic nervous system is very complex; the main nervous tracts underline the main muscles. The FMRFamidergic ventral nerve cord appears in the 6-day-old larva and remains in older stages. The excretory system forms as an unpaired ectodermal protrusion under the postoral ciliated band in front of the anus. The protrusion develops two branches (left and right), which then separate and form two protonephridia. The entoblast gives rise to other parts of digestive tract (cardiac sphincter, stomach, midgut). The posterior part arises from ectoderm. Mesoblast is the source of the coelomic lining of the preoral and (in future) tentacular 
coeloms, muscles, and blood corpuscles. In the early embryo, muscle cells and coelothelial cells have similar ultrastructures and form a continuous layer; all cells bear desmosomes. Then the myofilaments appear in the muscle cells, which lose desmosomes and become cross-striated. In summary, phoronids combine features of Protostomia and Deuteroatomia. Apparently, these features (nondeterministic cleavage of the egg; formation of blastule early in development; two sources of mesoderm; simultaneous occurrence of the mouth, nervous system, and muscles; etc.) are plesiomorphic and inherited from the common Bilateria ancestor. On the phylogenetic tree, phoronids should therefore be regarded as one of the basal groups of the Lophortochozoa.

How to cite this article: Temereva E.N., Malakhov V.V.2012. Embryogenesis in phoronids // Invert. Zool. Vol.9. No.1. P.1-39.

KEY WORDS: Phoronida, Lophotrochozoa, embryogenesis, development, phylogeny.

\section{Эмбриогенез фроронид}

\section{Е.Н. Темерева, В.В. Малахов}

Кафедра зоологии беспозвоночных, Биологический факультет Московского государственного университета имени М.В. Ломоносова, Москва 119992, Россия.

e-mail:temereva@mail.ru

РЕЗЮМЕ: Форониды - отдельный тип животного царства, положение которого среди других Bilateria коренным образом изменилось в результате анализа новых данных молекулярной филогенетики. Результаты последних лет уверенно свидетельствуют о положении форонид среди типичных Trochozoa. В то же время данные молекулярной филогении до сих пор не нашли очевидных доказательств со стороны сравнительной эмбриологии и морфологии. В работе представлен обзор имеющихся литературных данных, а так же собственные оригинальные результаты по раннему эмбриональному и личиночному развитию форонид. Показано, что дробления яйца у форонид может быть охарактеризовано как переходный тип между типичным радиальным и типичным спиральным. Типичным радиальным дробление форонид нельзя считать, поскольку у многих видов было описано наклонное положение борозд третьего, четвертого и последующих делений дробления. В то же время у форонид отсутствуют типичная для спирального дробления мозаика бластомеров, трохобласты, клетки креста и т.д. Недетерминированное дробление, при котором наклонное расположение борозд дробления позволяет сформировать бластулу уже на стадии 16 клеток, что чрезвычайно важно для развития в толще воды, повидимому, досталось форонидам от общего предка Bilateria, имевшего голопелагическое развитие. У видов, вынашивающих яйца и эмбрионы в кроне щупалец, последовательность меридиональных и широтных делений дробления позволяет сформировать эмбрион прямоугольной формы, которая является более удобной для постройки эмбриональных скоплений. Обнаружение у форонид хорошо выраженных двух источников целомической мезодермы - переднего и заднего — позволяет рассматривать эту группу как наиболее архаичную среди всех Bilateria. Источники 
мезодермы многоклеточные и формируются за счет иммиграции клеток из стенки архентерона (передняя мезодерма) или энтероцельно (задняя мезодерма). Органогенез начинается на стадии поздней гаструлы. Из эктобласта развиваются эпидермис и ресничные шнуры, нервная система, выделительная система и некоторые отделы пищеварительного тракта (пищевод и проктодеум). Эпидермис претерпевает дифференцировку и отличается по ультраструктуре в разных участках тела. У молодых личинок имеются только преоральный и посторальный ресничные шнуры. У личинок форонид реснички преорального шнура работают так же как у личинок других первичноротых: бьют спереди назад, тогда реснички посторального ресничного шнура работают как у вторичноротых: бьют спереди назад. Сигнальные серотонинэргические нейроны дифференцируются в эпидермисе апикальной пластинки. Серотонинэргические клетки появляются, но потом исчезают вдоль края преоральной лопасти, а также вдоль вентральной стороны тела, где они формируют продольный нервный ствол с парными нейронами и метамерными комиссурами. У молодой личинки серотонинэргическая нервная система состоит из апикального органа, который образуют монополяры и две группы (правая и левая) биполяров или мультиполяров, нерва щупалец, окологлоточного нервного кольца и двух кольцевых нервов телотроха. FMRFамидэргическая нервная система устроена более сложно и главные нервные тракты повторяют ход главных мышечных пучков. FMRFамидэргический вентральный нервный ствол появляется у шестидневной личинки и сохраняется на более поздних стадиях. Выделительная система закладывается непарным эктодермальным впячиванием, которое формируется под посторальным ресничным шнуром впереди кишечника. От этого впячивания отходят две ветви - левая и правая, каждая из которых несет группу из 7-10 терминальных клеток. Затем единое основание разделяется и формируются два протонефридия. Энтобласт дает начало некоторым отделам пищеварительного тракта: кардиальный сфинктер, желудок, средняя кишка. Задний отдел происходит из эктобласта. Мезобласт дает начало клеткам целомической выстилки преорального и, позднее щупальцевого целомов, мускулатуре и клеткам крови, которые появляются на более поздних личиночных стадиях. На ранних этапах развития мышечные клетки и клетки целомической выстилки не отличаются друг от друга по ультраструктуре и образуют единый слой, в котором все клетки связаны десмосомами. Затем в мышечных клетках появляются миофиламенты и утрачиваются десмосомы. На более поздних стадиях миофиламенты организуются по типу поперечнополосатой мускулатуры. Суммируя результаты можно заключить, что форониды - группа, сочетающая признаки первичноротых и вторичноротых. По-видимому, эти признаки (недетерминированное дробление яйца, формирование бластулы на ранних стадиях дробления, наличие двух источников целомической мезодермы, одновременное появление рта, нервной системы и мускулатуры и т.д.) унаследованы форонидами от общего предка Bilateria, а сами форониды, таким образом, занимает более базальное положение среди Lophotrochozoa.

Как цитировать эту статью: Temereva E.N., Malakhov V.V. 2012. Embryogenesis in phoronids // Invert. Zool. Vol.9. No.1. P.1-39.

КЛЮЧЕВЫЕ СЛОВА: форониды, Lophotrochozoa, эмбриогенез, развитие, филогения. 


\section{Introduction}

The Phoronida is a group of invertebrates with a unique body plan. The position of phoronids on the phylogenetic tree of Bilateria is still unclear and is a hotly debated topic in metazoan phylogeny. Traditionally, phoronids have been allied with brachiopods and bryozoans - all of which bear a ciliated, tentacular feeding apparatus called a lophophore - in the taxon Tentaculata (Hatschek, 1888) or Lophophorata (Hyman, 1959). The monophyly of Lophophorata, however, has been questioned by several authors. For example, V.N. Beklemishev (1964) inferred that metamorphosis of phoronids is similar to metamorphosis of bryozoans, and he merged both groups into one taxon - Podaxonia. In contrast, there is substantial molecular evidence that the Phoronida and Brachiopoda are closely related (Cohen et al., 1998; Cohen, 2000; Cohen, Weydmann, 2005; Santagata, Cohen, 2009). According to all these data, moreover, phoronids form a small taxon among the inarticulate brachiopods. In any case, the decision concerning relationships between the main groups of the Lophophorata does not help us define the position of the Lophophorata on the bilaterian phylogenetic tree.

The position of lophophorates among other Bilateria has been changed several times. Some authors concluded that the Lophophorata are protostomian animals (e.g., Hatschek, 1888; Grobben, 1908; Hyman, 1940; Marcus, 1958). Others regarded the Lophophorata as an archicoelomate group that is situated at the base of the Bilateria phylogenetic tree (Masrterman, 1900; Remane, 1949; Siewing, 1980). A third group of authors, who focused on comparative anatomy and embryology, considered the Lophophorata to be closely related to the Deuterostomia (e.g., Zimmer, 1973; Emig, 1977a; Lüter, 2000; Ax, 2001).

In recent zoological science, phoronids are regarded as trochozoans (Giribet, 2008; Paps et al., 2009), but their position among the Lophotrochozoa is still debated. Some molecular phylogenetic analyses have suggested a close relationship between phoronids and mollusks (Mal- lat, Winchell, 2002; Paps et al., 2009) or between phoronids and nemerteans (Dunn et al., 2008; Helmkampf et al., 2008; Hausdorf et al., 2010). In any case, these affiliations are based solely on molecular data and are not supported by any morphological or embryological data. Moreover, analyses based on comparative anatomy and embryology always indicate that phoronids are a sister group of the Deuterostomia (Remane, 1949; Siewing, 1980). This contradiction between molecular data and data from comparative anatomy and embryology reflects contradiction in other results of modern investigations. Thus, on the one hand, phoronids have all the features of deuterostomian animals such as radial cleavage of the egg (Emig, 1977b; Herrmann, 1986; Temereva, Malakhov, 2007), multicellular origin of the coelomic mesoderm (Herrmann, 1980; Zimmer, 1980; Temereva, Malakhov, 2007), and three coelomic compartments in the larva (Masterman, 1900; Temereva, Malakhov, 2006a) and the adult (Emig, Siewing, 1975; Temereva, Malakhov, 2011a). On the other hand, some data indicate the presence of trochozoan features in phoronid organization and development. Thus, spiral cleavage was discovered in several species (Rattenbury, 1954; Pennerstorfer, Scholtz, 2011), and some larvae and adults lack a preoral coelom (Bartolomaeus, 2001; Gruhl et al., 2005). At the same time, some principal aspects of phoronid embryogenesis have not been studied. These unstudied aspects concern the formation of the digestive tract and coelomic system, neurogenesis, and myogenesis. In this chapter, we provide new data about phoronid embryogenesis and a comparative analysis of phoronid embryogenesis.

\section{Formation of gametes and ferti- lization}

The development of oocytes and spermatozoa has studied in two phoronid species: Phoronopsis harmeri Pixell 1912 (see Reunov, Klepal, 2004; Temereva et al., 2011c) and Phoronis muelleri Selys-Longchamps 1903 (see Franzen, Ahlfors, 1980). 
Phoronids do not have special gonads, and germ cells develop in a special tissue called vasoperitoneal tissue (Fig. 1A). The ultrastructure and development of vasoperitoneal tissue were recently studied in $P h$. harmeri (Temereva et al., 2011). According to these data, cells of the vasoperitoneal tissue and oocytes rest on the blood capillaries (Fig. 1A), and cells of the vasoperitoneal tissue form a follicular layer around each oocyte; although the follicle covers the oocyte, it does not nourish it (Temereva et al., 2011). The mature oocyte has one large nucleus and one or several large nucleoli, which are visible even with a light microscope (Fig. 1B). Spermatozoa mature inside special lophophoral organs, which are present in mails of dioecious species and in all adult hermaphroditic species. The organization and ultrastructure of the lophophoral organ were described in several reports (Ikeda, 1903; Zimmer, 1967; Temereva, Malakhov, 2006b). According to these reports, lophophoral organs contain cavities in which the spermatophores form. The morphology of spermatophores has been described for two phoronid species (Zimmer, 1967). In Phoronis ijimai Oka 1897 (=Phoronis vancouverensis Pixell 1912), the spermatophore is ovoid and small. In Ph. harmeri, the spermatophore has a large spiral sail and a round basal pocket that contains spermatozoa (Fig. 1C). In some cases, the male can produce aggregations of spermatophores (Fig. 1D). One aggregation can contain two or three round pockets of different diameters. At the location where the sail contacts the pocket, there is a roundish socket (Fig. 1E). The pocket with spermatozoa is covered by a thin, transparent, massy layer (probably, mucous) with stuck grogs (Fig. 1F). The pocket surface bears many ovoid dents (Fig. 1E). Spermatophores can float in water, and the spermatozoa that they release into the water enter the female through the nephridial ducts. Once in the female's trunk coelom, the spermatozoa form large aggregations that float in the coelomic fluid (Fig. 1G) and then fertilize the eggs. Because fertilization occurs in the female's trunk coelom, fertilization in phoronids can be categorized as internal. The spawning occurs as a release of fertilized eggs or early embryos. Most eggs start to develop in the sea water, but the intriguing idea that contact with sea water triggers the cleavage of the egg is incorrect because cleavage (embryos with 2 or 4 blastomeres) in the trunk coelom has been documented (Selys-Longchamps, 1907; Rattenbury, 1953; Temereva, Malakhov, 2007).

\section{Early development}

Because early development of phoronids is still debated, it necessary to discuss and consider all relevant evidence. Moreover, phoronid species vary considerably with respect to egg cleavage, blastulation, and gastrulation.

\subsection{Egg cleavage}

Is cleavage spiral or radial?

Early development of phoronids was first described in detail by J. Rattenbury (1954), who worked with Phoronopsis viridis Hilton 1930 ( $=$ Ph. harmeri). According to Rattenbury, the eggs of $P h$. viridis and probably of all phoronids have spiral cleavage. Starting from the third division, the spindles arise in an oblique direction, and the degree of spindle inclination may vary between the cells of one embryo (Rattenbury, 1954). The third cleavage is approximately equal, the micromeres being the same size as the macromeres. As a result of the oblique position of the spindles, sister cells shift with respect to each other so that one lies closer to the animal pole and the other lies closer to the vegetal pole. Rattenbury (1954) traced the fate of each quadrant up to the late blastula stage and concluded that phoronids have equal, undetermined, spiral cleavage without specialised mesodermal cells, i.e., without teloblasts. The view that cleavage in phoronids is spiral received new support from the modern view that phoronids are closely related to typical spiralians. Some authors have suggested that spiral cleavage has been reduced in phoronids (Hejnol, 2010), and others have suggested that phoronids might exhibit a plesiomorphic or a second- 

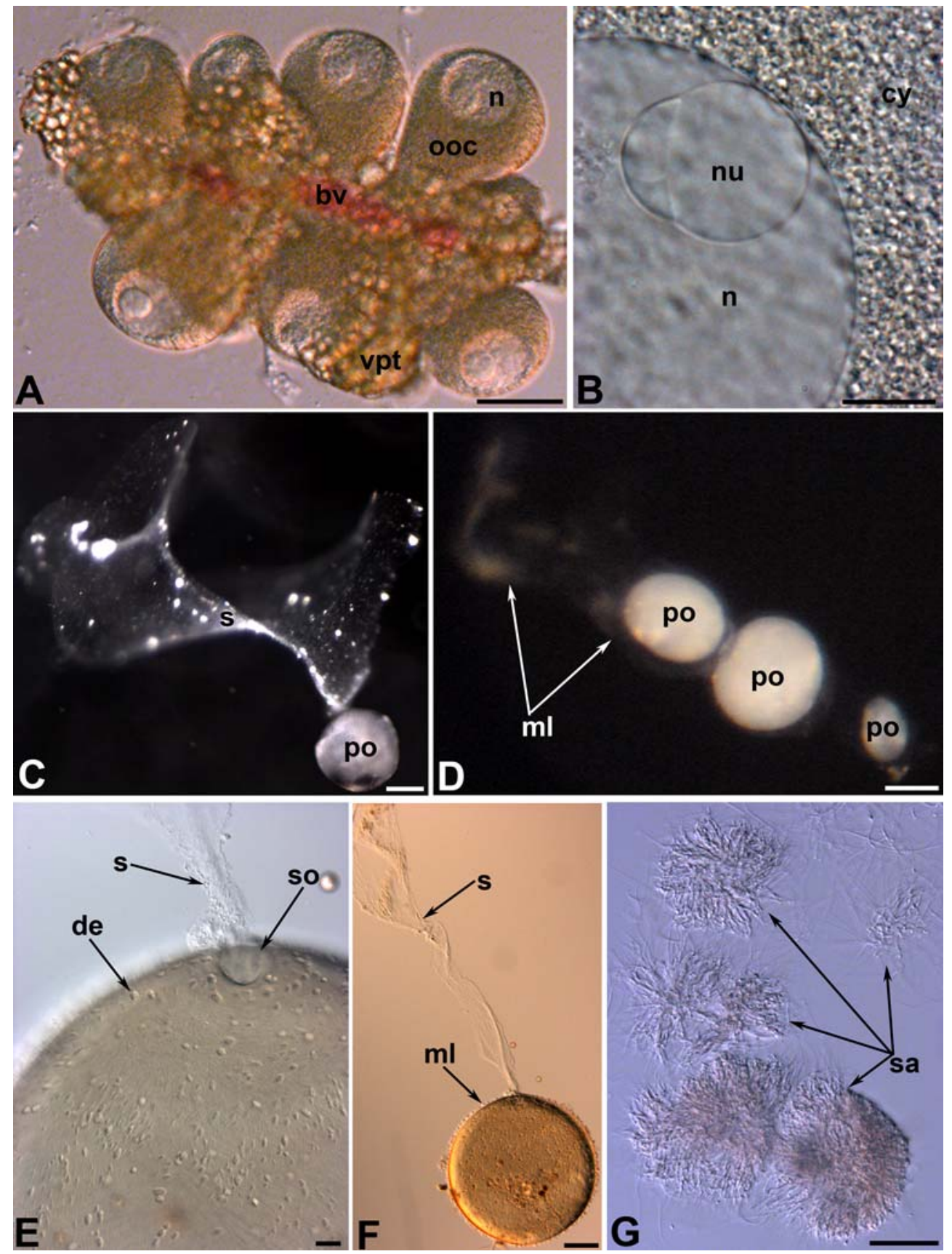

Fig. 1. Germ cells and spermatophore of Phoronopsis harmeri, live specimens, light microscopy. A - part of the blood capillary (bv) with oocytes (ooc) and vasoperitoneal tissue (vpt); B - part of the oocyte cytoplasm (cy) with a portion of the nucleus (n) and large nucleolus (nu); C - the spermatophore consists of a sail (s) and a pocket (po) with spermatozoa; D - aggregation of pockets (po), which are covered by a mucous layer (ml); E — spermatophore; the place of contact between sail (s) and pocket. A small socket (so) and dents (de) are indicated; F — general view of spermatophore pocket, which is covered by a mucous layer $(\mathrm{ml})$, and part of the sail (s); $\mathrm{G}$ - aggregations of spermatozoa (sa) from the coelomic fluid of a female. Scale bars: A, F $-50 \mu \mathrm{m} ; \mathrm{B}-10 \mu \mathrm{m} ; \mathrm{C}, \mathrm{D}-100 \mu \mathrm{m} ; \mathrm{E}, \mathrm{G}-1 \mu \mathrm{m}$. 
arily simplified spiralian condition (Pennerstorfer, Scholtz, 2011).

Our own data indicate that phoronid egg cleavage is closer to radial than spiral, although cleavage varies depending on the type of development (Malakhov, Temereva, 2000; Temereva, Malakhov, 2007). Phoronids exhibit three types of development (Emig, 1977b; Temereva, 2009). In the first type, which is termed holopelagic, embryos develop freely in sea water. In the second type of development, the embryos are retained in the lophophore up to the actinotroch stage. In the third type, which is termed lecitotrophic and which is exhibited only by Phoronis ovalis Wright 1856, the embryo develops without pelagic stages. We have studied embryonic development in two species, which exhibit the first and second types of development.

Ph. harmeri is a phoronid with the first type of development and releases eggs into the water. The egg is $90 \mu \mathrm{m}$ in diameter and is surrounded by a thin envelope (Fig. 2A). Before the first cleavage, the envelope becomes more amorphous and undulated (Fig. 2B). The furrow of the first division appears on the animal pole, and first division occurs on the meridional plane (Fig. 2C). One blastomere is somewhat larger than the other (Temereva, Malakhov, 2007). After the first cleavage, the blastomeres separate, and the difference in size is easily observed (Fig. 2D). The blastomeres then gradually approach each other, and difference in blastomere size becomes insignificant (Fig. 2E, F). The difference in size between the first two blastomeres has also been observed for several other phoronid species (Foettinger, 1882; Roule, 1900; Brooks, Cowles, 1905; Rattenbury, 1954; Emig, 1974, 1977b). Experimental studies of embryonic development in Ph. ijimai showed that the first groove is usually transverse to the anteriorposterior axis of the larval body, producing one anterior and one posterior blastomere (Freeman, 1991). Hence, in phoronids in which the first division is unequal, the larger blastomere may be located at either end of the embryo. Considering that the anterior end of the larva is larger than the posterior end (the spacious head lobe develops and immigration of primary mesoderm occurs in the anterior end), one could speculate that the larger blastomere corresponds to the anterior end of the embryo. According to other observations, cells of the animal pole are slightly smaller that those of the vegetal pole at the 8-blastomere stage (Rattenbury, 1954; Emig, 1977b). The cleavage inequality at this stage is often (but not always) pronounced in spiral embryogenesis. In these cases, the animal cells (the first quartet micromeres) give rise to the larval episphere, while the vegetative cells (first quartet of macromeres) give rise to the larval hypersphere. In phoronids, the inequality is often not detectable by observation with a light microscope, and cell fate of both pole blastomeres is determined at the 8-cell stage (Freeman, 1991). In gastrula, the descendants of animal blastomeres occupy the aboral pole region, whereas descendants of vegetal blastomeres occupy the periblastoporal region. In the actinotrocha, the animal blastomere descendants (together with the apical plate and the stretching of the ectodermal tier along the dorsal part of larval body) give rise to the ectoderm of the head lobe (above the ciliated band) (Freeman, 1991). This pattern is easily accounted for by accretion of the gastrula dorsal zone, resulting in displacement of the apical plate to the front of the embryo. However, in Phoronis pallid Silen 1952, for instance, a typical radial symmetry of blastomeres is observed at the 16-

\footnotetext{
Рис. 1. Половые клетки и сперматофоры Phoronopsis harmeri, световые фотографии живого материала.

A — часть кровеносного капилляра (bv) с ооцитами (ooc) и вазоперитонеальной тканью (vpt); В — часть цитоплазмы ооцита (cv) с участком ядра (n) и ядрышком (nu); C - сперматофор, состоящий из паруса (s) и мешка (ро) со спермиями; D - скопление мешков (ро), покрытых общей слизистой оболочкой (ml); Е - сперматофор; место контакта паруса (s) и мешка. Показано небольшое углубление (so) в основании паруса и ямки (de) на поверхности; F - общий вид мешка сперматофора, покрытого слизистой оболочкой (ml), и участка паруса (s); $\mathrm{G}$ - скопления сперматозоидов излеченных из целомической полости самки. Масштаб: A, F - 50 мкм; В - 10 мкм; C, D- 100 мкм; E, G-1 мкм.
} 

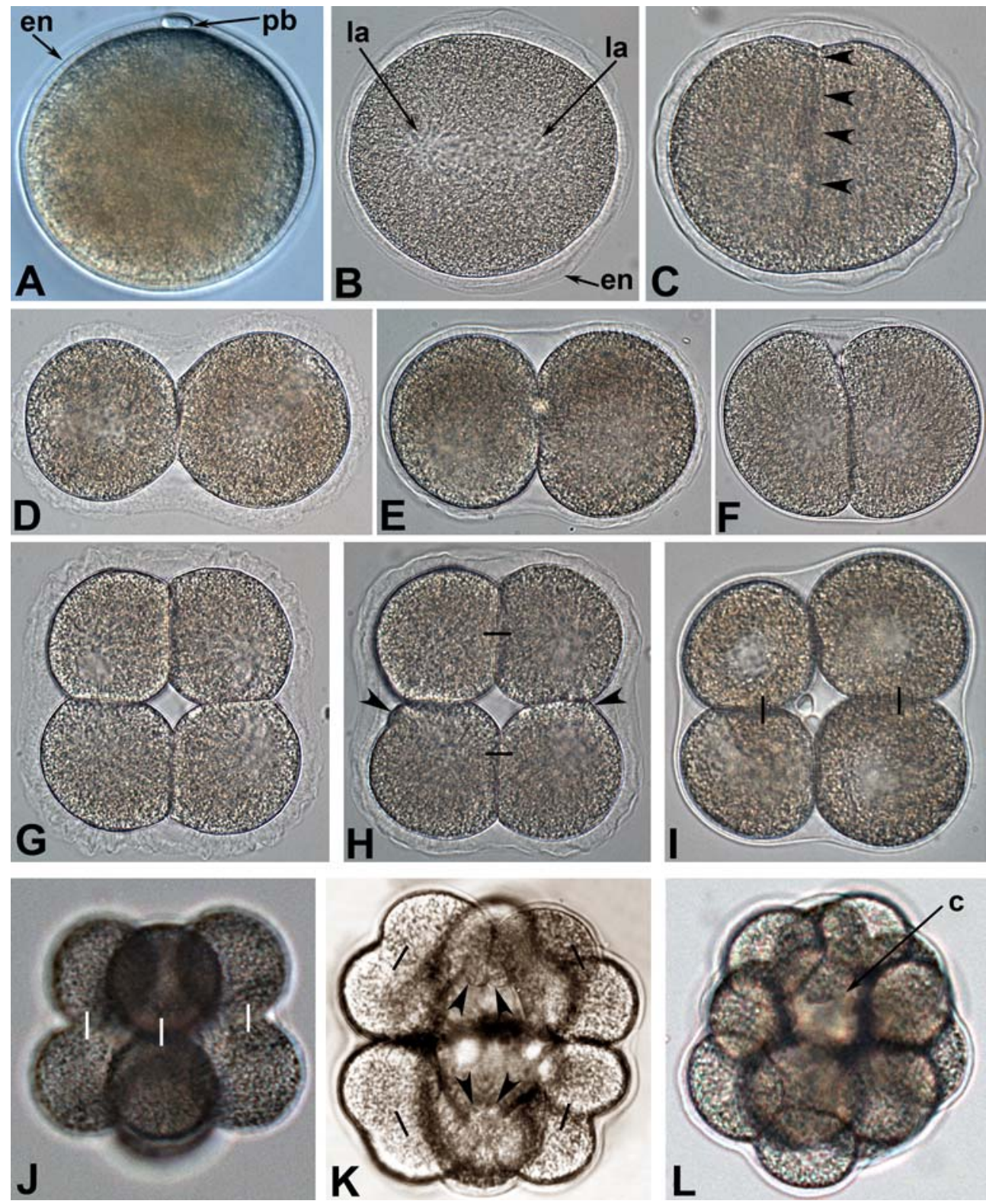

Fig. 2. Early cleavage of Phoronopsis harmeri, live embryo, light microscopy. A-D, F, J, K - lateral views are oriented with the animal pole to the top; E, G-I - animal view; L - vegetal view. Sister cells are connected by a line. Each stage is $90 \mu \mathrm{m}$ in diameter.

A - the egg with the polar body (pb) and envelope (en); B - the start of the first cleavage: two light areas (la) in the cytoplasm (two poles of spindle) appear and the envelope becomes amorphous; $\mathrm{C}$ - formation of the first cleavage furrow (arrowheads); D-F - stage of 2 blastomeres; D - blastomeres part from each other; the right blastomere is larger than the left; E - the gradual approach of the blastomeres; F - connivent blastomeres; G-I - the 4-blastomere stage; $\mathrm{G}$ - just after division: the envelope is amorphous; $\mathrm{H}$ - formation of inner protrusions (arrowheads) in two sister blastomeres; I - an embryo in which the blastomeres on the right are clearly larger than the blastomeres on the left; J typical shape of an 8-cell embryo in radial cleavage: animal blastomeres (top) are strictly juxtaposed with vegetal blastomeres (bottom); $\mathrm{K}$ - the start of the fourth division. Protrusions of blastomeres are marked by arrowheads; $\mathrm{L}$ the 16-cell stage: the embryo contains a small cavity (c). 
cell stage, and even a 32-celled blastula is not polarized (Santagata, 2004).

According to our data, the second cleavage furrow of $P h$. harmeri also forms on the meridional plane (Fig. 2G-I). Sister blastomeres part from each other, and the envelope forms many waves (Fig. 2G). Then the blastomeres approach, and some form a protrusion on the inner-lateral blastomere surface (Fig. 2H). When blastomeres approach, the envelope becomes smooth. In some embryos, the difference in size between blastomeres is evident at this stage (Fig. 2I).

The third cleavage furrows are oriented on the equatorial plane. The arrangement of blastomeres at the 8-cell stage is typical for radial cleavage and deuterostomian development in which the four vegetal blastomeres are strictly juxtaposed with four animal blastomeres (Fig. $2 \mathrm{~J})$. The fourth cleavage furrows are oblique, and the spindles are situated at angle with respect to animal-vegetal axis (Fig. 2K). In some blastomeres, short, thick protrusions form. They point toward a small cavity that has formed as a result of the oblique positions of the spindles (Fig. 2K). Thus, the small blastocoel cavity appears at the 16-cell stage (Fig. 2L). The oblique orientation of the fourth cleavage furrows and the early formation of the blastocoel are in accord with the holopelagic type of development, because the blastocoel cavity promotes the buoyancy of the embryo. Oblique furrows have been described in other phoronid species. Thus, according to Herrmann (1986), the third cleavage furrows in Ph. muelleri are orientated at an angle to the animal-vegetal axis. This angle can vary from 10 to 45 degrees. After that, the animal and vegetal blastomeres are shifted by some angle relative to the animal-vegetal axis. Herrmann (1986) emphasized that this event is not evidence of spiral cleavage. Interesting, Zimmer (1964) describes 8-cell embryos in which animal blastomers have shifted relative to vegetal blastomers. Rattenbury (1954) and Pennerstorfer with Scholtz (2011), who dealt with the oblique positions of the furrows of the third and subsequent divisions, assumed that a spiralian pattern characterized the cleavage in phoronids. In our opinion, the oblique position of division furrows correlates only with the type of development and cannot be regarded as typical spiral cleavage.

In Ph. harmeri, the swimming blastula contains a spacious blastocoel. The blastoderm is noticeably thicker at the vegetal pole than at the animal pole. Each cell bears the cilium. There is a tuft of long cilia on the animal pole of the swimming blastula (Temereva, Malakov, 2007).

Ph. ijimai exhibits the second type of development (Emig, 1977b; Malakhov, Temereva, 2000; Temereva, Malakhov, 2009). This species broods embryos up to the young larval stage. In Ph. ijimai, the three first cleavages are similar to those in Ph. harmeri. The furrows of fourth and fifth cleavage are meridional, almost parallel to each other. As a result, the 32-cell embryo consists of two 16-cell plates. The bricklike shape of the embryo is maintained in subsequent stages. The blastula is compressed along the animal-vegetal axis, and there is no spacious blastocoel within.

Рис. 2. Раннее дробление Phoronopsis harmeri, живые эмбрионы, световая микроскопия. А-D, F, J, $\mathrm{K}$ - вид сбоку, анимальный полюс сверху; E, G-I - вид с анимального полюса; L - вид с вегетативного полюса. Дочерние бластомеры соединены линиями. Диаметр каждой стадии 90 мкм. $\mathrm{A}$ - яйцо с полярным тельцем (pb) и оболочкой (en); В — начало первого деления дробления: появляются две светлых области (la) в цитоплазме (два поля веретена деления) и оболочка становится морщинистой и аморфной; $\mathrm{C}$ - формирование борозды первого деления дробления (отмечена наконечниками); D-F — стадия 2 бластомеров; D - бластомеры расходятся; правый бластомер больше левого; Е - постепенное сближение бластомеров; F - сблизившиеся бластомеры; G-I - стадия 4 бластомеров; G - сразу после деления: видна аморфная оболочка; Н - формирование внутренних выпячиваний (указаны наконечниками) у дух сестринских бластомеров; I - эмбрион, у которого отчетливо видна разница между крупными бластомерами (справа) и более мелкими бластомерами (слева); J — типичная для радиального дробления форма 8 клеточного зародыша: анимальные бластомеры (сверху) располагаются строго над вегетативными (снизу); К - начало четвертого деления дробления. Выпячивания бластомеров указаны наконечниками; L - 16-клеточный эмбрион с полостью (с) внутри. 

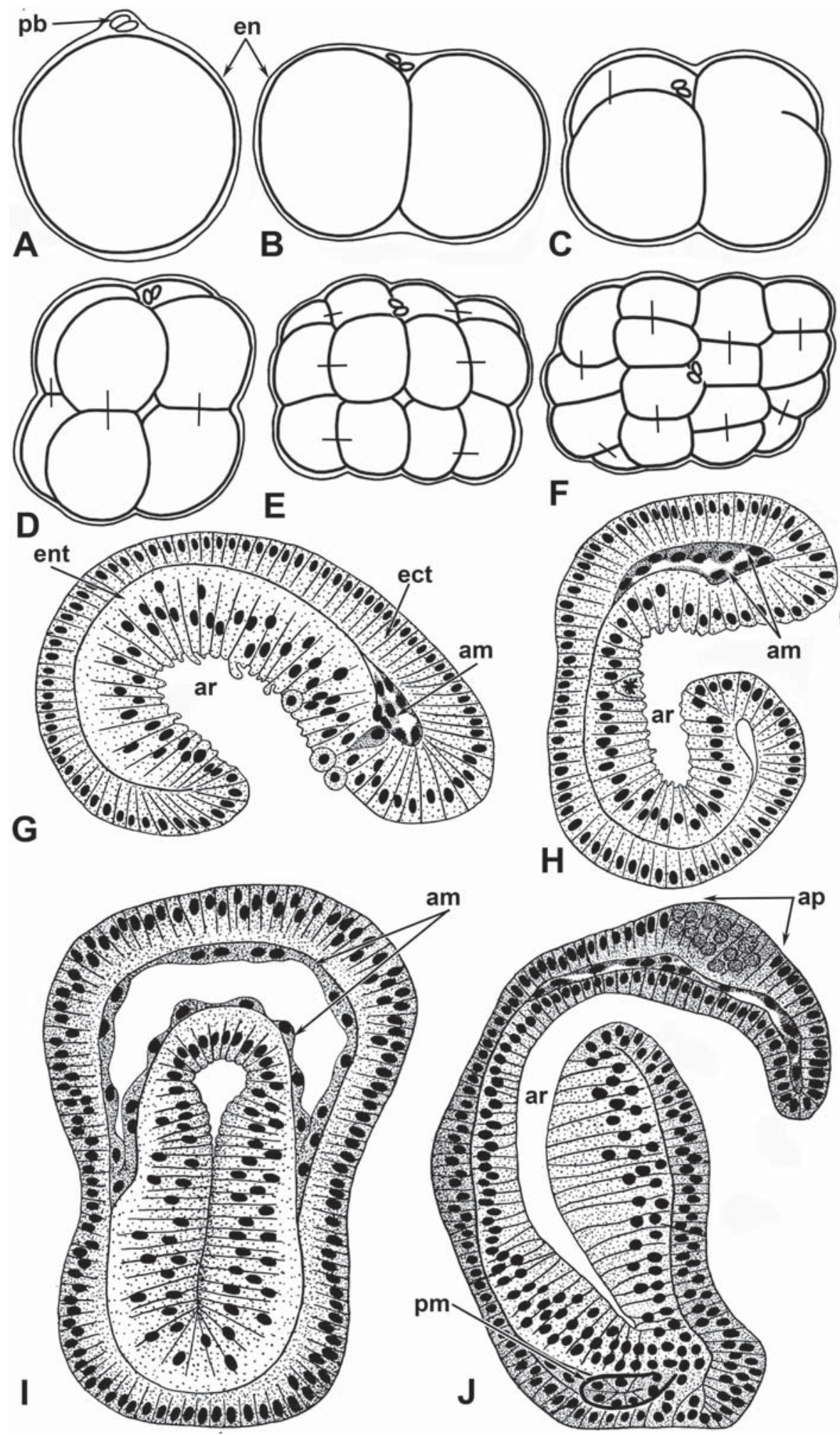
Overall, egg cleavage in phoronids usually follows a radial rather than a spiral pattern but varies depending on type of development. In phoronids with holopelagic development (e.g., $P h$. harmeri), oblique furrows of the fourth and subsequent divisions allow the formation of a spherical blastula containing a spacious blastocoel that is very important for embryo buoyancy. Phoronids with brooding (e.g., Ph. ijimai), in contrast, lack oblique furrows although the regular alternation of meridian and latitudinal divisions is altered in some positions. The meridional position of the furrows of the $4^{\text {th }}$ and the $5^{\text {th }}$ divisions facilitates the formation of an embryo with a brick-like shape, a shape that allows the embryos to be closely packed within the aggregation. The second type of phoronid development in which larvae are released relatively late seems to be more advanced than the first type.

Although some aspects of phoronid cleavage superficially resemble spiral cleavage, especially in phoronids with holopelagic development, phoronid development and typical spiral development are significantly different. Phoronid development lacks the kind of specific mosaic of blastomeres that is characteristic for true spiral development. Rosette cells, cross cells, and trochoblasts, all of which are characteristic of spiral development, have never been reported in phoronids. We therefore believe that phoronid development should not be interpreted as being derived from a spiral development. More likely, phoronid cleavage demonstrates the first steps away from undetermined radial cleavage that seems to be plesiomorphic for bilaterian clade towards the spiral cleavage which is characteristic for trochozoans as such. From this standpoint, phoronids probably with other lophophorates occupy a basal position within the lophotrochozoan clade in comparison with more advanced trochozoans.

\subsection{Gastrulation and mesoderm for- mation}

In Ph. harmeri, blastulae actively swim in sea water. The gastrulation starts with the flattening of the vegetal blastoderm (Fig. 4A). The apical tuft of long cilia shifts onward, and the direction of the animal-vegetal axis changes it curves (Fig. 4A). The blastoderm then migrates into the blastocoels (Fig. 4B). The prima-

Fig. 3. Early development, gastrulation, and mesoderm formation in Phoronis ijimai. A-F - drawings of live embryos extracted from the embryonic mass. The position of polar bodies (pb) indicates the animal pole of the embryo. Sister cells are connected by lines; A-E - lateral view; F — animal view; G-J - pictures of histological sections of embryos.

A - the egg with two polar bodies ( $\mathrm{pb}$ ) enveloped by the thin envelope (en); B - two blastomeres; C - completion of the second cleavage; D - eight blastomeres; E - sixteen blastomeres; F - thirty-two blastomeres. The embryo has a brick-like shape; $\mathrm{G}$ - early gastrula stage with differentiated ectoderm (ect) and entoderm (ent), primary archenteron (ar), and primary anterior mesoderm precursor (am). Sagittal section, the anterior pole is on the right; $\mathrm{H}$ - later gastrula with large archenteron (ar) and anterior mesoderm (am). Sagittal section, the anterior pole is at the top; I - later gastrula stage with a spacious blastocoel in the anterior part, which is lined by cells that arose from the anterior mesodermal precursor (am). Frontal section, the anterior pole is at the top; $\mathrm{J}$ - preactinotrocha; the formation of the posterior mesodermal precursor (pm). The larva has a large apical plate (ap) and archenteron (ar). Sagittal section.

Рис. 3. Раннее развитие, гаструляция и формирование мезодермы у Phoronis ijimai. A-F - рисунки живых эмбрионов, извлеченных из эмбриональных скоплений. Полярные тельца маркируют анимальный полюс. Сестринские бластомеры соединены линиями. A-E - вид сбоку; F - вид с анимального полюса; G-J - рисунки гистологических срезов эмбрионов.

$\mathrm{A}$ - яйцо с двумя полярными тельцами (pb), одетое тонкой оболочкой (en); B — два бластомера; C - окончание второго деления дробления; D - стадия 8 бластомеров; Е - стадия 16 бластомеров; F — стадия 32 бластомеров; $\mathrm{G}$ - ранняя гаструла с дифференцированной эктодермой (ect) и энтодермой (ent), архентероном (ar) и зачатком передней мезодермы (am). Сагиттальный срез, передний конец тела - сверху; Н - поздняя гаструла с обширным архентероном (ar) и передней мезодермой (am). Сагиттальный срез, передний конец тела — сверху; I - поздняя гаструла с обширным бластоцелем в передней части зародыша; бластоцель выстлан клетками, происходящими из переднего целомического зачатка (am). Фронтальный срез, передний конец тела - сверху; $\mathrm{J}$ - преактинотроха, формирование заднего целомического зачатка (pm). Показаны крупная апикальная пластинка (ap) и архентерон (ar). Сагиттальный срез. 
ry blastopore looks like a round orifice in the center of the vegetal pole (Fig. 4C). It elongates on the anterior-posterior axis to occupy the major portion of the back half of the ventral area of the embryo. Blastopore lips gradually close in at its middle and later at the posterior region. In later gastrula stages, the blastopore has a narrow posterior part and a wide anterior part (Fig. 4E). Then the posterior part closes and is replaced by a deep groove on the ventral side of the gastrula (Fig. 4F). The remnant of the blastopore at its anterior region forms the mouth. The gastrula has a spacious blastocoel, which is especially voluminous in its anterior part (Fig. 4D). The archenteron occupies the middle and posterior part of the embryo (Fig. 4D).

In $P h$. ijimai, gastrulation proceeds in the maternal lophophore. Cilia develop on the cells of the blastoderm by the beginning of gastrulation, but embryos still remain aggregated. Gastrulation combines several events: the ingrowth of the vegetal pole blastoderm, the bending of the embryo, and the invagination of the vegetal blastoderm. The primary blastopore looks like a depression at the centre of the vegetal pole (Fig. $5 \mathrm{~A})$. Cells of the vegetal depression have distinctly prominent apical parts that distinguish the blastopore area from other regions of the embryo that are formed by more flattened cells (Fig. 5B). The primary blastopore then elongates and looks like a narrow slit (Fig. 5C). The cells in the vegetal pole retain their peculiar shape. The narrow blastocoel between the ectoderm and invaginated entoderm is filled with mesodermal cells (Fig. 5D). The blastopore gradually elongates and closes in the middle. The blastoporal grove is clearly visible on the ventral side of the embryo (Fig. 5E). The mouth and anus develop as deep depressions at the opposite ends of the blastoporal groove (Fig. $5 \mathrm{~F})$.

In both species (Ph. ijimai and $P$ h. harmeri), the mesoderm originates from two sources: anterior and posterior. In Ph. harmeri, the anterior precursor arises from the anterior wall of the archenteron in the early gastrula stage. Initially, it looks like a small bulb (Fig. 4B) but then it grows and gives rise to a large mass of cells that fill the anterior part of the blastocoel (Fig. 4D). Some mesoderm cells remain in the anterior part of the embryo (Fig. 4G) but some migrate backwards, forming two lateral tiers along both sides of the archenteron (Fig. 4H). The anterior mass of mesoderm cells gives rise to the preoral coelom (see below) and the muscle of the preoral lobe (Fig. 4I). The lateral cell tiers form the

Fig. 4. Gastrulation and mesoderm formation in Phoronopsis harmeri. A-E, H-I - photographs of live embryos, light microscopy; F, G - fixed embryos stained with phalloidin, confocal microscopy.

A - lateral view of the early gastrula stage with a long apical tuft (at), a shifted apical plate (ap), a spacious blastocoel, and a flat blastoderm (vp) of the vegetal pole; B - the next stage with an archenteron (ar), a large apical plate (ap), and the precursor of the anterior mesoderm $(\mathrm{am})$, lateral view; $\mathrm{C}$ - the same stage on the ventral side, showing the archenteron (ar) and elongated blastopore (bp); D - later gastrula stage with apical tuft (at) on the anterior pole, small blastocoels (bl), and cells that migrated from the anterior mesoderm (arrowheads). Lateral view, the ventral side is on the right; E - dorsal view of the later gastrula stage with apical plate (ap), archenteron (ar), and blastopore (bp), which has started to close posteriorly; F - the same stage from the ventral side, 3D-reconstruction by Amira ver. 5.2.2. The blastopore (bp) and ventral deep grove (arrowheads) are shown; G - Z-projection of several middle slides of the stack with a mass of mesodermal cell (arrowheads), archenteron (ar), and the blastopore (bp); $\mathrm{H}$ - lateral view of the later gastrula stage with a spacious blastocoel (bl) in the anterior part, an archenteron (ar), and two lateral tiers (lt) of cells that migrated from the anterior pole; I - the next stage with the closed cavity of the preoral coelom (c1), apical tuft (at), and archenteron (ar). Scale bars: A-C $-25 \mu \mathrm{m}$; D-I $-15 \mu \mathrm{m}$.

Рис. 4. Гаструляция и формирование целомической мезодермы у Phoronopsis harmeri. A-E, H-I фотографии живых животных; световая микроскопия; F, G- фиксированные эмбрионы, окрашенные фаллоидином; конфокальная лазерная сканирующая микроскопия.

А - ранняя гаструла (вид сбоку) с длинным теменным султанчиком (at), смещенной вперед апикальной пластинкой (ap), обширным бластоцелем и уплощенной бластодермой вегетативного полюса (vp); В - следующая стадия, вид сбоку, показаны архентерон (ar), крупная апикальная пластинка (ap), зачаток передней мезодермы $(\mathrm{am}) ; \mathrm{C}$ — та же стадия со стороны вентрального полюса, показаны архентерон (ar) и вытянутый бластопор (bp); 

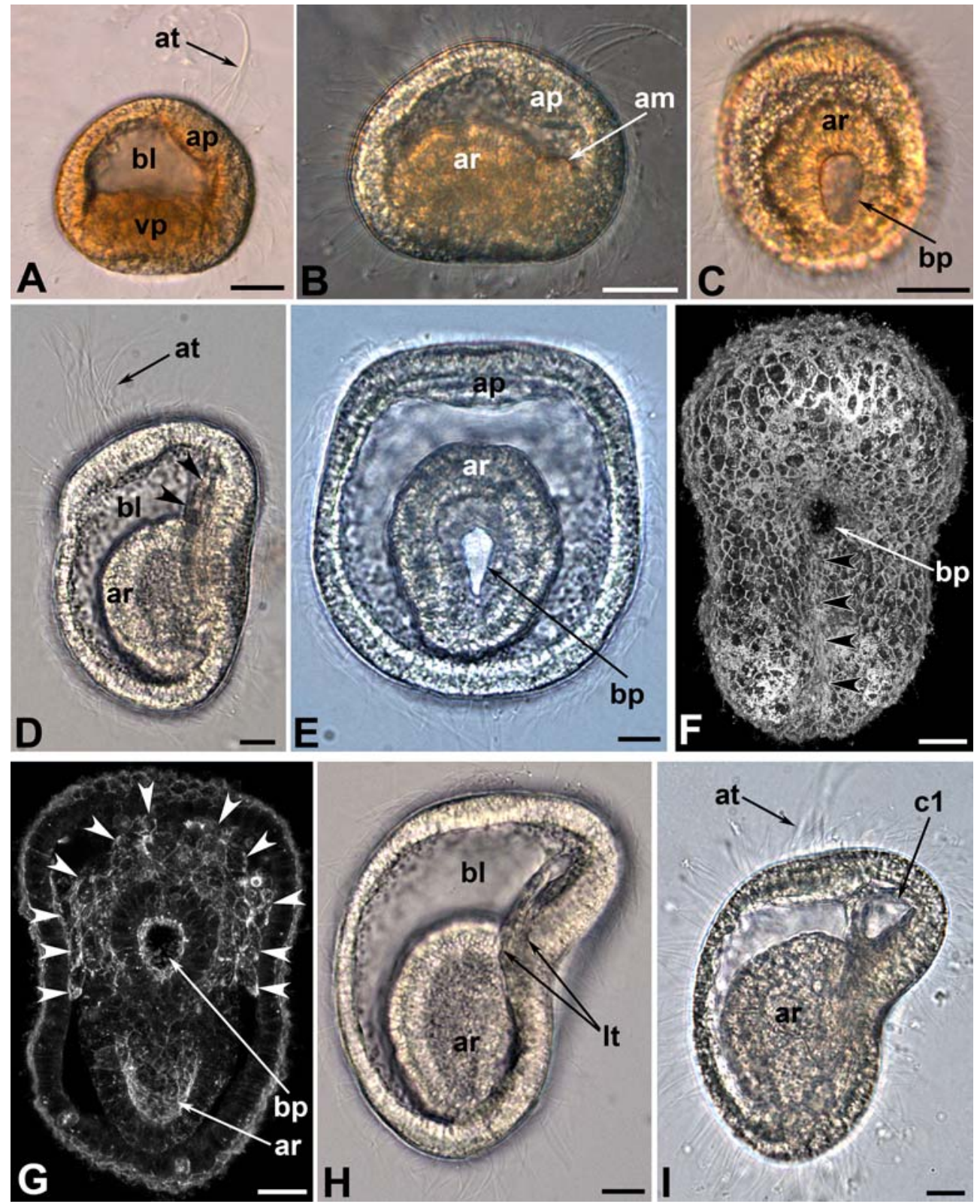

D - поздняя гаструла с теменным султанчиком (at) на переднем конце тела, небольшим бластоцелем (bl), и клетками (указаны наконечниками), иммигрировавшими из переднего мезодермального зачатка. Вид сбоку, вентральная сторона - справа; Е - поздняя гаструла (вид с дорсальной стороны), показаны: теменная пластинка (ap), архентерон (ar) и бластопор (bp), начавший замыкаться сзади наперед; F — та же стадия с вентральной стороны, 3D-реконструкция, сделанная в программе Amira вер. 5.2.2. Показаны бластопор и вентральный желобок (наконечники), проходящий вдоль линии замыкания бластопора; $\mathrm{G}-\mathrm{Z}$-проекция нескольких слайдов из середины стопки, показано скопление мезодермальных клеток (наконечники), архентерон (ar) и бластопор (bp); H - поздняя гаструла с обширным бластоцелем (bl) в передней части тела, архентероном (ar) и двумя латеральными рядами клеток (lt), выселившихся из стенки архентерона (вид сбоку); I - следующая стадия с замкнутой полость предротового целома (c1), теменным султанчиком (at) и архентероном (ar). Масштаб: А-C 25 мкм; D-I - 15 мкм. 
muscle system of the hyposphere and tentacles. The posterior mesodermal precursor appears in early larval stages (Fig. 6A). The posterior mesoderm precursor first forms as a small evagination at the border between the midgut and hindgut. Then the precursor buds off becoming a horseshoe-shaped body (Fig. 6B), which embraces the intestine dorsally and on both sides (Fig. 6C). Later in development, two branches of the metacoel "horseshoe", which are easily observed in live larvae (Fig. 6D), meet on ventral the side, thus forming the ventral mesentery.

In Ph. ijimai, two precursors of the coelomic mesoderm can be recognized in histological sections (Fig. 3G-J). The anterior one also arises from cells that migrate from the anterior wall of the archenteron (Fig. 3G-I); the posterior one forms by enterocoely at the border between the hindgut and midgut (Fig. 3J).

According to most authors, mesodermal cells consist of cells that migrated from the frontal and lateral archenteron walls (Selys-Longchamps, 1902; Brooks, Cowles, 1905; Zimmer, 1980; Emig, 1974; Herrmann, 1986). Thus, Brooks and Cowles (1905) argue that the budding clumps primarily form the preoral coelom (protocoel) with two descending tiers of mesoderm later giving rise to meso- and metacoels. In the view of Rattenbury (1954), who inferred that spiral cleavage occurred in phoronids, the mesoderm originates from quadrants A, B, and C. Ikeda (1901) discovered that the mesoderm in $P h$. vancouverensis originated from cells that migrate from the archenteron wall and from the formation of paired temporal pouches, from which mesodermal clumps bud off. Zimmer (1980) indicated that the proto- and mesocoel form from $30-40$ cells that migrate frontally and ventrolaterally from the archenteron, whereas the metacoel originates from $6-10$ cells of the archenteron wall near the junction between the gut and stomach. Later, those cells aggregate to form a U-shaped body around the sides and dorsal part of the gut. A schizocoel forming inside this body gives rise to the definitive trunk coelom.

According to our data, the mesoderm in phoronids has a dual origin, anterior and poste- rior, and this has been proved in experiments with cell labeling in $P h$. vancouverensis (Freeman, Martindale, 2002). The mesoderm of this species includes cells labeled around both the mouth and anus, and forms at the border of the ecto- and endoderm, both of which contribute to its origin (Freeman, Martindale, 2002).

Two origins for the mesoderm (anterior and posterior) are characteristic of other groups of Bilateria. Thus, in the Spiralia, the precursor of the posterior mesoderm is the $4 \mathrm{~d}$ blastomere, whereas the anterior mesoderm originates from the descendants of blastomeres $2 \mathrm{a}, 2 \mathrm{~b}, 2 \mathrm{c}$, or $3 \mathrm{a}$ and $3 b$ and gives rise to pharynx muscles (Boyer et al., 1998; Henry, Martindale, 1998; Lartillot et al., 2002a). In chordates, the posterior mesoderm is the mesoderm of the tail bud, and the anterior mesoderm is the so-called prechordal mesoderm (Seifert et al., 1993; Kiecker, Niehrs, 2001). The mesoderm also has two origins in crustaceans, where the bulk of the mesoderm comes from the posterior portion of the embryonic plate (Weygoldt, 1961; Anderson, 1967; Behesch, 1969). In many groups of crustaceans, on the other hand, the so-called preantennal mesoderm segregates anteriorly in the embryo (Weygoldt, 1961; Benesch, 1969), thus giving rise to the muscles of the labium superius, pharynx, and eye-stalks.

The anterior and posterior mesoderm precursors are topologically associated with the mouth and anus, which within the framework of comparative anatomy are the products of the segregation of the slit-like blastopore of a radially symmetric ancestor (Sedgwick, 1884; Jagersten, 1955). Interestingly, in both chordates and invertebrates, the regions of the anterior and posterior mesoderm precursors express the homeobox genes «Brachiury», «goosecoid», and «fork head» (Bassham, Postlethwait, 2000; Tagawa et al., 2001; Technau, 2001; Lartillot et al., 2002b; Takade et al., 2002). Homologous genes express in Cnidaria circularly around mouth opening (Technau, Bode, 1999; Broun et al., 1999; Scholz, Technau, 2003). This suggests that the two precursors associated with the anterior and posterior ends of the slit-like blastopore descended from a primarily circular re- 
gion of mesoderm formation in a radially symmetrical ancestor that split in the evolution of the Bilateria.

In phoronids, the anterior mesoderm precursor forms at the anterior tip of the slit-like blastopore at the ecto-endoderm junction. The posterior precursor develops at the edge of the endodermal gut and ectodermal proctodeum, i.e., at the region corresponding to the posterior blastopore tip.

\section{Organogenesis}

Specific larval organs begin to form in the later gastrula stage. First, the primary muscles and nervous system appear, and then the digestive tract forms. At the same time, the shape of embryo changes and the ciliated bands arise. The channels of the protonephridia and the posterior precursor of the coelomic mesoderm originate simultaneously. After that, the body area under the tentacle ridge grows, the telotroch appears around the anus, and the trunk coelom acquires a sack-like shape. The tentacle coelom forms in older larvae; then the blood masses originate and become large and red before metamorphosis. The tentacular ridge forms protrusions, which are the tentacles. The number of tentacles increases with age. In midlarval stages, the metasomal sack occurs on the middle line of the ventral side under the tentacles. We have studied all the steps of Ph. harmeri organogenesis. As is the case for all Bilateria, organs and tissues of phoronids arise from three germ layers: the ectoblast, entoblast, and mesoblast.

\subsection{Ectoblast}

In phoronids, the epidermis (including ciliated bands), nervous system, larval excretory system, esophagus and proctodaeum arise from the ectoblast.

\subsubsection{Epidermis}

In preactinotroch larvae, which do not feed and does not have ciliated bands, the epidermis is formed by monociliate cells that do not have evident differences in shape and height throughout the body (Fig. 7A). The dorsal body wall has the least height and is composed of cuboidal cells with round nuclei bearing nucleoli (Fig. 7B). The epidermis of the oral field, apical plate, and preoral lobe is identical in height and is formed by cylindrical cells (Fig. 7C). Nucleus occupies the center of the cell. The apical cytoplasm of all cells contains large transparent vesicles (Fig. 7B, C). These vesicles can be found in all cells of the embryo and apparently arise from cortical granules of the egg. The basal cytoplasm of most epidermal cells have retained solitary yolk granules (Fig. 7A-C).

In the young actinotrocha and in all later stages, epidermal cells lack apical transparent vesicles and yolk granules. Differences between the epidermis of different body parts then become more evident (Fig. 7D). At first, the preoral and postoral ciliated bands appear; then the telotroch forms (Fig. 7D). All ciliated bands are formed by monociliate, high, columnar cells with elongated nuclei. Cells of the preoral ciliated band contain bundles of thin filaments, which extend along the lateral walls of the cell (Fig. 7E). The postoral ciliated band contains the so-called latero-frontal cilia, which bear nine thick, long microvilli and motionless cilia. In more advanced stages, these cilia form two rows along the lateral sides of each tentacle and are involved in particle capture (see Bullivant, 1968; Gilmour, 1978; Strathmann and Bone, 1997; Riisgård, 2002). The latero-frontal cells can be visualized by staining with phalloidin because the long microvilli contain actin microfilaments (Fig. 7G). Moreover, these microfilaments extend into the cell cytoplasm and surround the nucleus, as revealed by confocal laser scanning microscopy (CLSM) (Fig. 7G). The telotroch is the thickest ciliated band and is formed by columnar cells (Fig. 7F). The desmosomes between these cells are located on the lateral walls, and the apical portions of the cells unattached to each other (Fig. 7F). Cells of the telotroch epidermis have a long vertical rootlet, which passes from the apical cell part to the basal cell border. 

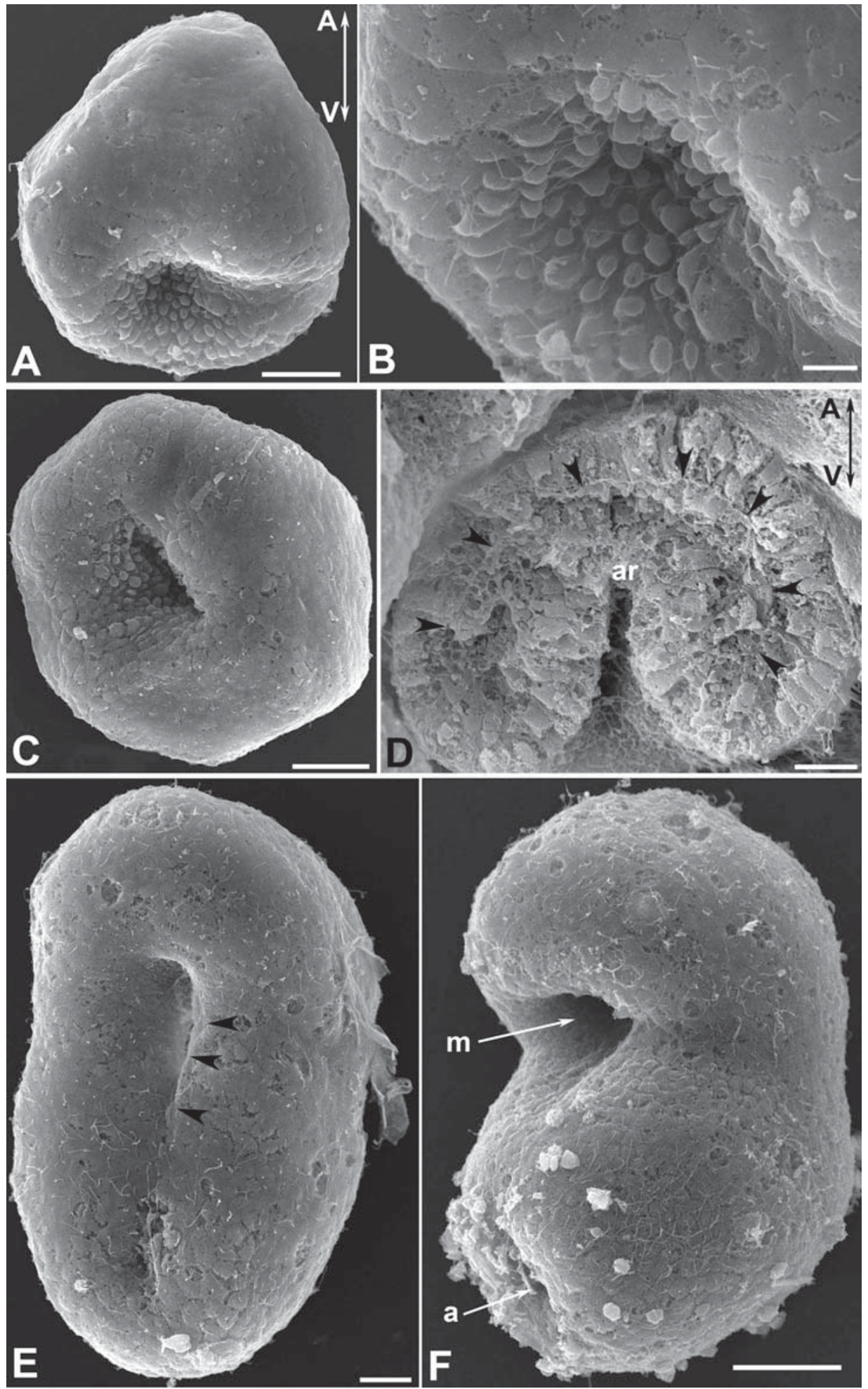
The thick epidermis of the oral field (the area between the mouth and tentacles), apical plate, and preoral lobe is formed by columnar cells with well-developed apical net of thin microfilaments (Fig. 7H). The nuclei are ovalshaped in these cells. The thin epidermis of the dorsal, lateral, and ventral body wall is composed of short, flat cells, which have a large surface area (Fig. 7I). The nuclei in these cells usually have an irregular form: they are curved or horseshoe-like in shape.

The formation of specialized epidermis along the ciliated bands is a common character for most ciliated Bilateria larvae. In phoronid larvae, cilated bands are formed by monociliate cells. Such organization of ciliated bands is known in deuterostomian larvae: tornaria and dipleurula (Strathmann, Bonar, 1976; Nielsen, 1987; Dautov, Nezlin, 1992; Lacalli, Gilmour, 2001). Some trochozoan larvae have monocilate cells in ciliated bands (larvae of Oweniidae) (Gardiner, 1978; Nielsen, 1987; Smart, Dassow, 2009). Nevertheless, in most trochozoan larvae, ciliated bands are formed by multiciliate cells.

Ciliated bands participate in larval locomotion in water and in the capture of food particles. Usually, the telotroche works as an organ of locomotion whereas the preoral and postoral ciliated bands surround the mouth and create a water current that moves food particles into the mouth. The Bilateria contains two groups of animals that create the water current with either an upstream- or a down-stream collecting system (Nielsen, 1987). The upstream collecting system has been described in adult phoronids, bryozoans, brachiopods, and pterobranchia (Nielsen, 1987; Nielsen, Riisgård, 1998). The down-stream collecting system is known in adult entoprocts, annelids, and sipunculids (Nielsen, 1987). Two types of collecting systems also occur in larvae. In "upstream larvae", cilia of the preoral ciliated band beat from posterior to anterior, whereas cilia of the postoral ciliated band beat from anterior to posterior. This type of collecting system was described in echinodermate and hemichordate larvae. The second type of larval type collecting system - downstream filtration - occurs in typical trochozoan larvae (e.g., trochophore). In these larvae, cilia of preoral ciliated band beat from anterior to posterior, whereas cilia of postoral ciliated band beat from posterior to anterior.

According to our data concerning actinotrocha, the preoral ciliated band beats from anterior to posterior, whereas the postoral ciliated band beats from anterior to posterior. Thus, in phoronid larvae, the preoral ciliated band works in the same manner as in trochozoan larvae, whereas the postroral ciliated band works in the same manner as in deuterostomian larvae. The same pattern with respect to the activities of preoral and postroral ciliated bands was described in cyphonautes, which are larvae of bryozoans (Strathmann, McEdwards, 1986; Strathmann, 2006).

Fig. 5. Early development of Phoronis ijimai, scanning electron microscopy (SEM).

A - the start of gastrulation, formation of the depression on the vegetal pole. Lateral view; B - fine morphology of the ventral depression, the apical portions of the vegetal cells look like bubbles; $\mathrm{C}$ - ventral view of the gastrula stage with a slit-like blastopore in the centre of the vegetal pole; D - the same stage; longitudinal section. The deep, narrow cavity of the primary archenteron (ar) is in the centre. The upper border of the blastocoel is indicated by arrowheads; E- ventrolateral view of the later gastrula stage with the blastoporal groove (arrowheads) along the ventral body side; F — ventrolateral view of the young actinotrocha with mouth (m) and anus (a). Scale bars: A, C, F - $20 \mu \mathrm{m} ; \mathrm{B}-5 \mu \mathrm{m} ; \mathrm{D}, \mathrm{E}-$ $10 \mu \mathrm{m}$.

Рис. 5. Раннее развитие Phoronis ijimai, сканирующая электронная микроскопия (CEM).

А - начало гаструляции; формирование вдавления в центре вегетативного полюса зародыша. Вид сбоку; В впячивание вегетативного полюса: апикальные части клеток вздуты и выглядят как пузыри; С — гаструла, вид с вегетативного полюса: виден щелевидный бластопор; D — та же стадия; продольный срез. Глубокая узкая полость в центре — архентерон (ar). Верхняя граница бластоцеля указана наконечниками; E — поздняя гаструла с бластопоральным желобком (указан наконечниками) вдоль вентральной стороны тела, вид с вентро-латеральной стороны; F - молодая актинотроха со ртом (m) и анусом (а), вид с вентро-латеральной стороны. Масштаб: А, C, F - 20 мкм; B - 5 мкм; D, E - 10 мкм. 


\subsubsection{Nervous system}

The development of the phoronid nervous system has been studied in $\mathrm{Ph}$. vancouverensis by immunochemistry (Hay-Schmidt, 1990a) and in Ph. harmeri by confocal microscopy and transmission electron microscopy (TEM) (Temereva, 2012; our unpublished data). Although the results of both investigations are generally similar, Ph. vancouverensis and Ph. harmeri differ in the details of early neurogenesis. According to our data, Ph. harmeri neurogenesis is characterized by the presence of nervous elements that have not been found before in phoronids (Temereva, 2012; our unpublished data).

According to Hay-Schmidt (1990) and our data, first nerve cells differentiate in the epidermis of the apical plate. We have shown that perikarya first appear with the formation of mesodermal cells (and their derivatives - muscles) and the mouth. This simultaneous formation of the nervous system, muscular system, and mouth may reflect some processes in evolutionary history when the organism changed from feeding on micro-particles to feeding on macroparticles. Neurotransmitters are first generated in epidermal cells, which are in close contact with the mesodermal cells (the future muscle cells).

In $P h$. vancouverensis, the first perikarya contain catecholamine and serotonin (HaySchmidt, 1990a). Catecholaminergetic cells appear in the centre of the apical plate, but then disappear, and new catecholamine-containing perikarya originate in the epidermis of the preoral lobe without connection to the apical plate (Hay-Schmidt, 1990a: Fig. 1a, b). Radial catecholamine-containing processes extend from these perikarya to the edge of the preoral lobe. Catecholamine-containing neurites were found in the neuropil, along the edge of the preoral lobe, along the tentacular ridge, in each tentacle, and around the anus (Hay-Schmidt, 1990a).

Serotonergic perikarya also arise in the apical plate and are evident there throughout larval development (Hay-Schmidt, 1990a). As shown in our work, in Ph. harmeri, the first neurons appear in the epidermis of the apical plate in the middle gastrula stage (Fig. 8A). The number of serotonergic perikarya increases with age. In the epidermis of the apical plate, serotonergic perikarya are located along the perimeter of the apical plate and arranged in the shape of a horseshoe with two dorsal branches (Fig. 8B, D). This horseshoe-like structure forms the basis of the larval apical organ. A horseshoe-shaped apical organ has been described in several phoronid larvae by several authors (HaySchmidt, 1989, 1990b; Lakalli, 1990; Santagata, Zimmer, 2002; own data). As shown in our research, the apical organ in advanced larvae of Ph. harmeri is composed of two types of perikarya: monopolar and multi- or bipolar (Fig. 8B). The first bipolar perikarya arise from monopolar perikarya, which lose apical parts with cilia and plunge into the epidermis of the apical plate. The monopolar perikarya are arranged along the perimeter of the apical organ, whereas the multior bipolar perikarya are located in the base of the epidermis of the apical plate and form two lateral groups (right and left) (Fig. 8B).

Additional serotonergic perikarya appear around the apical plate in Ph. vancouverensis (Hay-Schmidt, 1990a) and along the edge of the preoral lobe in Ph. harmeri (own data).

The first serotonergic neurites extend from the apical organ along the lateral and dorsal sides of the preoral lobe and collar region (upper portion of the hyposphere) in Ph. vancouverensis (Hay-Schmidt, 1990a) and along the dorso-lateral sides in Ph. harmeri (own data). According to Hay-Schmidt (1990a), in older Ph. vancouverensis larvae, three pairs of major serotonergic "nerves" (probably these are neurite bundles) extend from the apical organ. In addition to these main "nerves", there are radial "nerves" (probably neurite bundles) of the preoral lobe, which extend from the apical organ to the nerve on the edge of the preoral lobe, and the posterior nerve ring around the anus (HaySchmidt, 1990a). According to our data for $P h$. harmeri larvae, only two serotonergic neurite bundles arise from the apical organ: the median neurite bundle of the preoral lobe and the tentacular neurite bundle. The latter starts as two dorso-lateral branches, which are formed by 


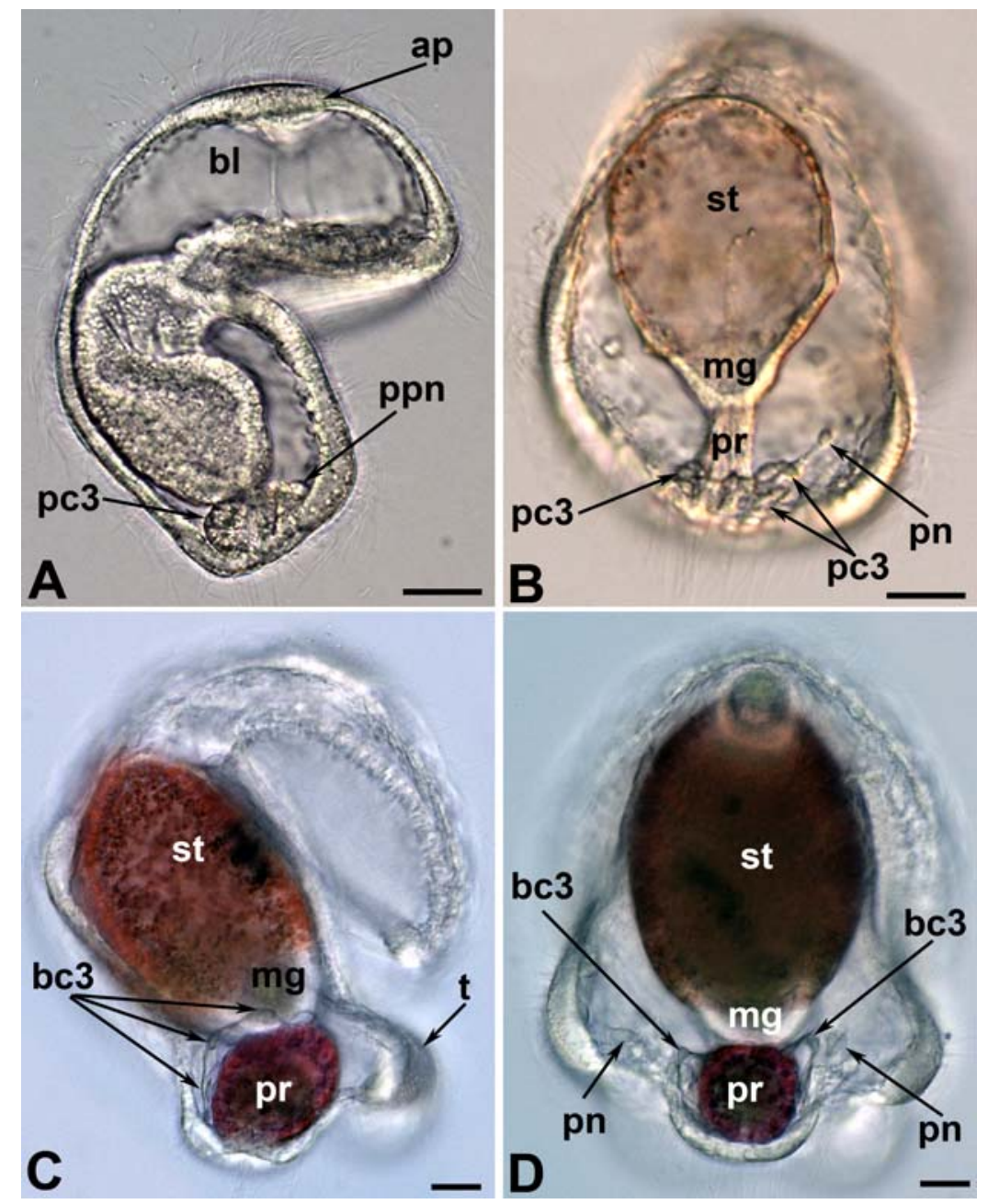

Fig. 6. Development of the trunk coelom in Phoronopsis harmeri, photographs of live animals, light microscopy.

A - lateral view of the later gastrula stage; the ventral side is on the right. The apical plate (ap), spacious blastocoels (bl), dorsal precursor of posterior mesoderm (pc3), and ventral precursor of protonepridium (ppn) are evident; B - a 6-day-old larva; a dorsal view showing the stomach (st), midgut (mg), proctodaeum (pr), right protonephridium (pn), and the precursor of the posterior mesoderm ( $\mathrm{pc} 3$ ), which surrounds the proctodaeum; C - a 9-day-old larva; a lateral view showing the stomach (st), midgut (mg), proctodaeum (pr), and border of the trunk coelom (bc3); D - the same larva, dorsal view. The same parts of digestive tract (stomach, midgut, and proctodaeum), paired protonephridia (pn), and trunk coelom (bc3) are indicated. Scale bar $20 \mu \mathrm{m}$.

Рис. 6. Развитие туловищного целома у Phoronopsis harmeri. Фотографии живых личинок, световая микроскопия.

А — поздня гаструла, вид сбоку, вентральная сторона справа. Обозначены апикальная пластинка (ар), обширный бластоцель (bl), дорсальный зачаток задней мезодермы (pc3) и вентральный зачаток протонефридиев (ppn), В - шестидневная личинка, вид сзади. Показаны: желудок (st), средняя кишка (mg), задняя кишка (pr), правый протонефридий (pn) и зачаток задней мезодермы (pc3), который окружает заднюю кишку; $\mathrm{C}$ - девятидневная личинка; вид сбоку, показны желудок (st), средняя кишка (mg), задняя кишка (pr) и граница туловищного целома (bc3); D - та же личинка, вид сзади. Отмечены те же части пищеварительного тракта (желудок, средняя кишка, задняя кишка), парные протонефридии (pn) и туловищный целом (bc3). Масштаб 20 мкм. 


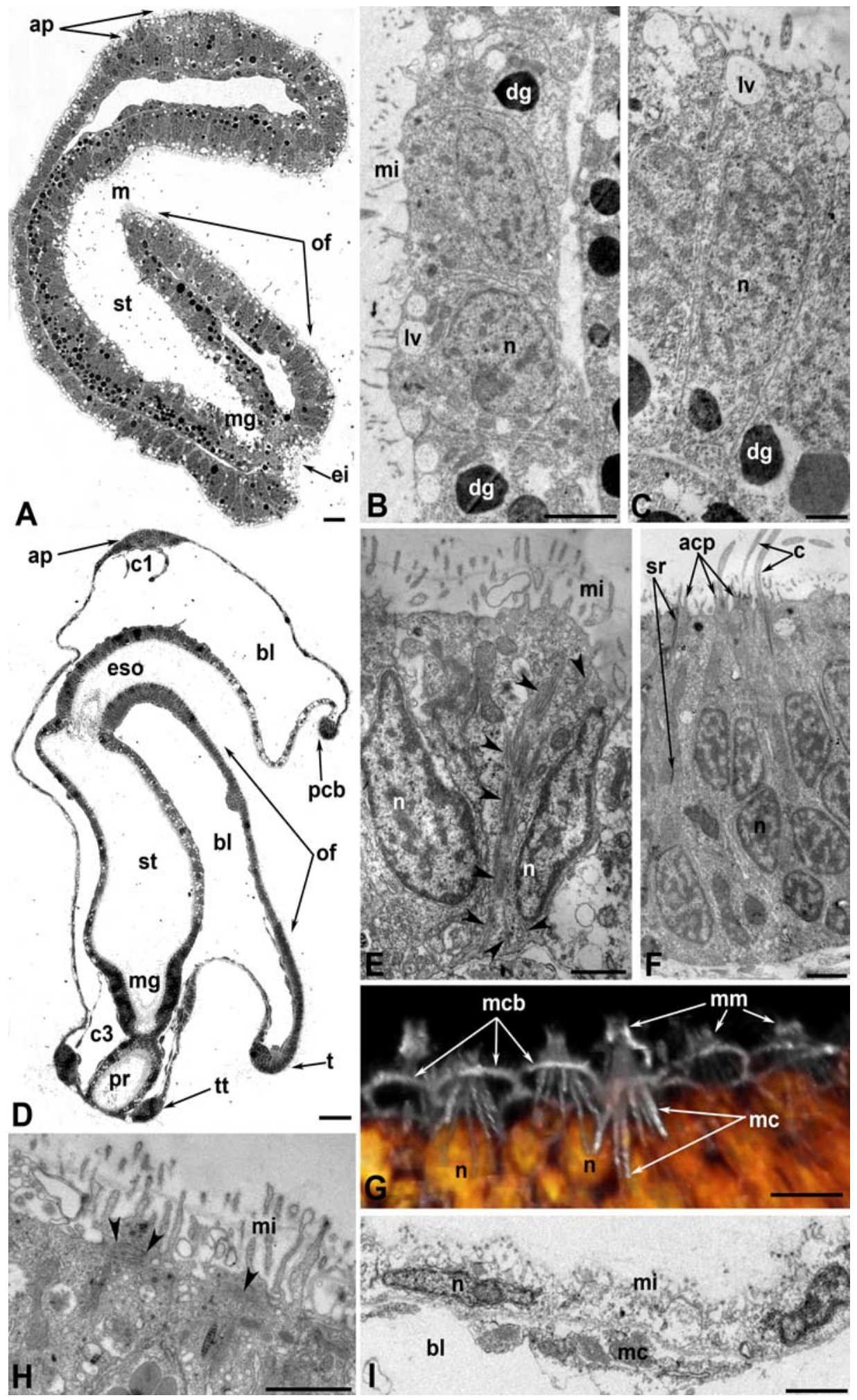


several thin neuritis and connect to each other via dorsal commissure. These dorso-lateral branches fuse on the ventral side and form several loops into each tentacle. In addition to the two main serotonergic neurite bundles in $P h$. harmeri, there are weak neurite bundles along the edge of the preoral lobe, a thick neurite bundles around the anus, and a nerve ring around the esophagus and cardiac sphincter. At some stage of development, unusual nerve elements are evident in Ph. harmeri larva. Thus, 6-dayold larvae have a ventral nerve cord, which extends from the oral nerve ring to the tentacular neurite bundle. The cord is composed of two longitudinal ventro-lateral nerves with paired bipolar perikarya and thin commissures between them (see Temereva, 2012).

The FMRFamide-reactive nervous system appears at later stages than the serotonergic nervous system. At early stages, FMRFamide-

Fig. 7. Organization of the epidermis in the preactinotrocha (A-C) and in the 13-day-old actinotrocha (DI) of Phoronopsis harmeri.

A - sagittal semi-thin section of preactinotrocha showing the general anatomy: apical plate (ap), mouth (m), stomach (st), midgut (mg), oral field (of), and posterior ectodermal invagination (ei) opposite the midgut; B - fine structure of the dorsal side of the epidermis. Longitudinal section showing round nucleus (n) with nucleolus, branched microvilli (mi), vacuoles with transparent content (lv), and electron-dense granules (dg); C - fine structure of the epidermis of the oral field showing elongated nuclei (n), vacuoles with transparent content (lv), and electron-dense granules (dg); D - sagittal semi-thin section of the 13-day-old actinotrocha showing the general anatomy and difference in organization of epidermis between different body parts, including the apical plate (ap), preoral coelom (c1), preoral ciliated band (pcb), esophagus (eso), stomach (st), midgut (mg), proctodaeum (pr), oral field (of), spacious blastocoel (bl), trunk coelom (c3), tentacle (t), and telotroch (tt); E - details of the fine structure of the preoral ciliated band epidermis showing the presence of longitudinal filaments (arrowheads), which run along the nucleus (n); $\mathrm{F}$ - the portion of the telotroch epidermis with long cilia (c), long striated rootlet (sr), and free apical parts of cells (apc); G - laterofrontal cells in the postoral ciliated band. The larva was stained with phalloidin (actin filaments appear gray) and hoechst (nuclei glow) and analysed by Amira ver. 5.2.2. A 3D-reconstruction showing actin microfilaments in microvilli (mm) above apical cell borders, which are also stained because contain microfilaments (mcb) along apical perimeter, and microfilaments in the cytoplasm (mc) around the nucleus (n); H - apical parts of cells of the oral field epidermis. Microvilli (mi) and apical net of microfilaments (arrowheads) are indicated; I - fine structure of the dorsal side epidermis, which is formed by flat cells with microvilli (mi) and irregular nuclei (n) and which are underlain by muscles cells (mc) of the blastocoel (bl). Scale bars: A $-5 \mu \mathrm{m}$; B, E, F, H, I $-2 \mu \mathrm{m}$; C $-1 \mu \mathrm{m}$; D $-50 \mu \mathrm{m}$; G $-4 \mu \mathrm{m}$.

\section{Рис. 7. Организация эпидермиса преактинотрохи (A"C) и 13-дневной личинки (D”I) Phoronopsis} harmeri.

A - сагиттальный полутонкий срез преактинотрохи, показывающий общую анатомию: апикальная пластинка (ap), рот (m), желудок (st), средняя кишка (mg), оральное поле (of) и заднее эктодермальное впячивание (ei) напротив средней кишки; В - ультраструктура эпидермиса дорсальной стороны тела, продольный срез. Показаны округлое ядро (n) с ядрышком, ветвящиеся микровилли (mi), вакуоли с прозрачным содержимым (lv) и электронно-плотные гранулы (dg); C - ультраструктура эпидермиса орального поля; показын вытянутое ядро (n), вакуоли с прозрачным содержимым (lv) и электронно-плотные гранулы (dg); D — сагиттальный полутонкий срез 13-дневной актинотрохи, показана общая анатомия и видны различия в организации эпидермиса разных участков тела. На срезе обозначены: апикальная пластинка (ap), преоральный целом (c1), предротовой ресничный шнур (pcb), пищевод (eso), желудок (st), средняя кишка (mg), задняя кишка (pr), оральное поле (of), обширный бластоцель (bl), туловищный целом (c3), щупальце (t) и телотрох (tt); E- детали ультраструктурной организации эпидермиса преорального ресничного шнура. Наконечниками указаны продольные филаменты, проходящие вдоль вытянутого ядра (n); F - участок эпидермиса телотроха сллинными жгутиками (c), длинными исчерченными корешками (sr) и свободными апикальными участками клеток (apc); $\mathrm{G}$ - латерофронтальные клетки посторального ресничного шнура. Личинка окрашена фаллоидином (актиновые филаменты - серые) и хёкстом (ядра оранжевые), реконструкция проведена в программе Amira вер. 5.2.2. 3D-реконструкция показывает актиновые микрофиламенты в микровиллях (mm) над апикальной поверхностью, которая так же окрашивается фаллоидином, поскольку в цитоплазме по периметру клетки проходит актиновые микрофиламенты (mcb), и микрофиламенты в цитоплазме (mc), проходящие пучками вдоль ядра (n); H - апикальные части клеток эпидермиса орального поля; показаны микровилли (mi) и апикальная сеть микрофиламентов (указаны наконечниками); I — тонкое строение эпидермиса дорсальной стороны тела, который образован уплощенными клетками с микровиллями (mi) и неправильной формы ядрами (n) и со стороны бластоцеля (bl) подостланы мышечными клетками (mc). Масштаб: А -5 мкм; B, E, F, H, I - 2 мкм; C - 1 мкм; D - 50 мкм; G - 4 мкм. 

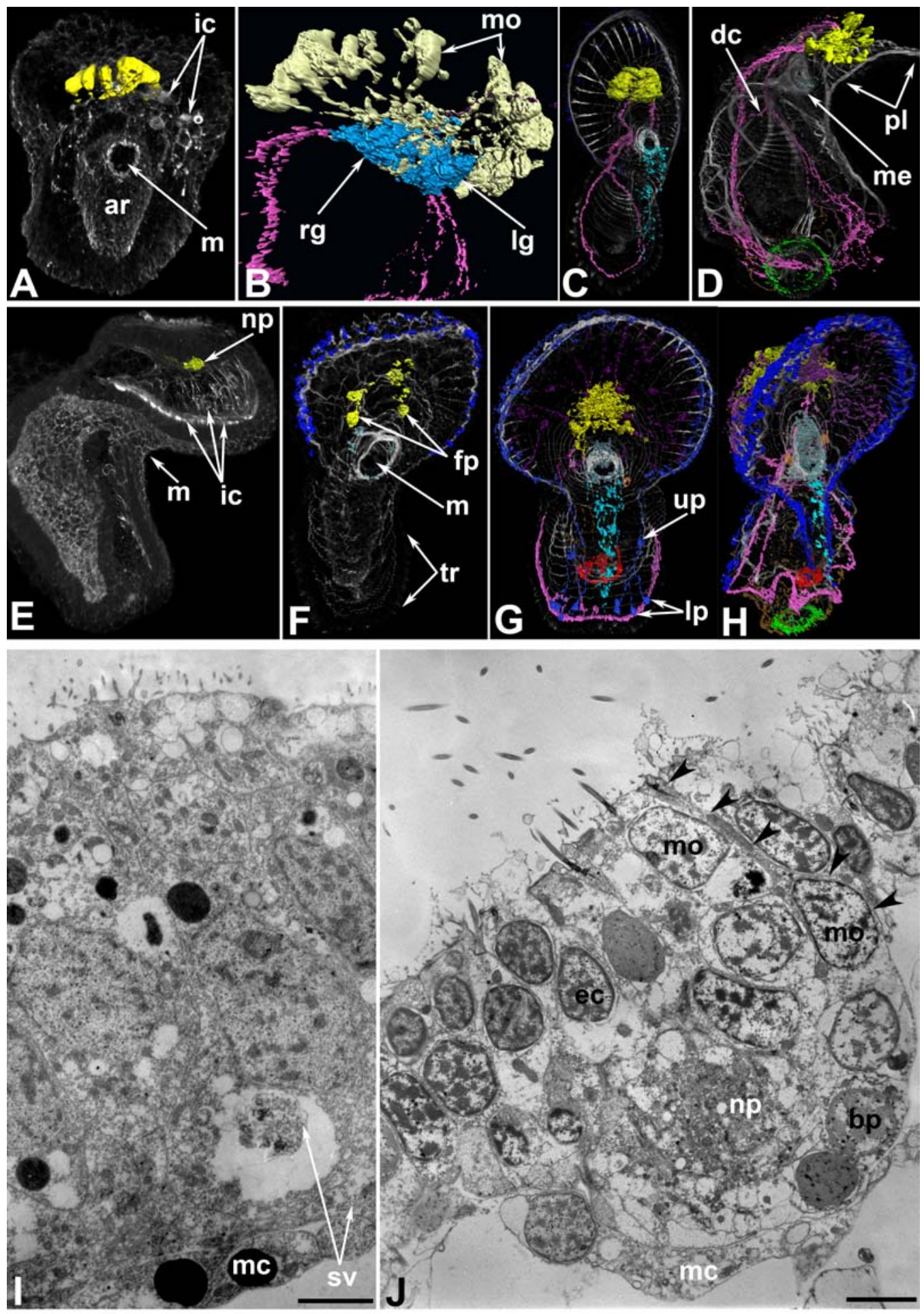
Fig. 8. Organization of the nervous system at different stage of Phoronopsis harmeri development. A-H 3D-reconstructions made with Amira ver. 5.2.2. The anterior pole is oriented vertically. A-D - organization of the 5HT nervous system at different stages. E-H - organization of the FMRFamide nervous system at different stages. Color: yellow — apical organ; pink — tentacular neurite bundle; light green — telotroch neurite bundles; dark green — net around the proctodaeum; cyan — ventral nerve cord; pale blue — oral nerve ring; dark blue - marginal neurite bundle of the preoral lobe edge, two pairs of ventro-lateral neurites of the oral field, the upper ventro-lateral perikarya, and the lower ventro-lateral perikarya; brown - trunk neurites; magenta — neurites and perikarya of the preoral lobe; orange — large neuron near the mouth; grey/ white - muscular system and all actin-containing structures (parietal cytoplasm, microvilli, etc.). I, Jultrastructure of the apical plate, sagittal sections.

A - frontal view of the middle gastrula indicating cells (ic) that migrated from the archenteron (ar) and the mouth (m); B - organization of the apical organ in an advanced larva showing the monopolar perikarya (mo - gold), left (lg) and right ( $\mathrm{rg}$ ) groups of bipolar or multipolar perikarya (light blue), which give rise two branches of the tentacular nerve (pink), view from below; C - the organization of the $5 \mathrm{HT}$ nervous system in a 6-day-old larva, ventro-lateral view. A weak signal is evident around the proctodaeum (dark green) and along the edge of the preoral lobe (dark blue). Numerous perikarya are located along the ventral side of the oral field; D - lateral view of a 24-day-old larva with the preoral lobe ( $\mathrm{pl}$ ), strong muscles of esophagus (me), and dorsal commissure (dc) between two branches of the tentacular nerve; $\mathrm{E}$ - lateral view of later gastrula stage with the FMRFamide-reactive neuropil (np), cells (ic) derived from anterior mesoderm, and the mouth (m); F - ventro-lateral view of a young actinotrocha with first FMRFamidereactive perikarya (fp), mouth (m), and tentacular ridge (tr); $\mathrm{G}$ - ventral view of a 6-day-old larva; the upper (up) and lower (lp) perikarya of ventro-lateral nerves are indicated; $\mathrm{H}$ - ventro-lateral view of a 24-day-old larva; I epidermis of apical plate in the later gastrula stage: the cells have the same fine structure; some of them contain synaptic vesicles (sv). Epidermis is underlined by mesodermal cells (mc); J - epidermis of the apical plate in a 6day-old larva: the cells have a different fine structure. Monopolar perikarya (mo), bipolar or multipolar perikarya (bp), the neuropil (np), epidermal cells (ec), and mesodermal cells (mc) are evident. The flask-shape perikaryon is indicated by arrowheads. Scale bars: $\mathrm{I}-2 \mu \mathrm{m} ; \mathrm{J}-2.5 \mu \mathrm{m}$.

Рис. 8. Организация нервной системы на разных стадиях развития Phoronopsis harmeri. A-H - 3Dреконструкции, сделанные в программе Аmira вер. 5.2.2. Передний конец тела - сторого сверху. А$\mathrm{D}$ - организация серотонинэргической нервной системы на разных стадиях развития. Е-H организация FMRFамидэргической нервной системы на разных стадиях развития. Цветами обозначены: желтый - апикальный орган; розовый - щупальцевый нерв; светло-зеленый — нервы телотроха; темно-зеленый — нервная сеть вокруг задней кишки; голубой — вентральный нервный ствол; темно-синие - маргинальный нерв преоральной лопасти, две пары вентро-латеральных нервов орального поля, группы верхних и нижних вентро-латеральных перикариев; коричневый нервы теловища (гипосферы); пурпурный — отростки и тела нервных клеток преоральной лопасти; оранжевый - нейроны с обеих сторон ото рта; серый/белый - мышечная системы и все актинсодержащие структуры (париетальная цитоплазма клеток, микроворсинки и т.д.). I, J ультраструктура апикальной пластинки; сагиттальные срезы.

А - средняя гаструла, вид спереди, показаны клетки (ic), иммигрировавшие из стенки архентерона, и рот (m); В - организация апикального органа у поздней личинки; вид снизу.Показаны монополярные перикарии (то) и нейропиль, образованный их отростками (показаны золотым цветом), а так же левая (lg) и правая (rg) группы биполярных или мультиполярных перикариев (светло-голубой), которые дают начало двум дорсальным ветвям щупальцевого нерва (розовый); C- организация серотонинэргической нервной системы у 6-дневной личинки; вентро-латерально. Слабый сигнал различим вокруг задней кишки (темно-зеленый) и вдоль края преоральной лопасти (показан темно-синим). Многочисленные перикарии располагаются вдоль вентральной стороны орального поля; D - вид сбоку на 24-дневную личинку с преоральной лопастью (pl), мощно развитыми мышцами пищевода (me) и дорсальной комиссурой (dc) между двумя ветвями щупальцевого нерва; Е — поздняя гаструла, вид сбоку. Обозначены FMRMFамидэргический нейропиль (np), клетки (ic), выселившиеся из стенки архентерона и рот (m); F - молодая актинотроха вентро-латерально с первыми FMRFамидэргическими перикариями (fp), ртом (m) и щупальцевым валиком (tr); G - 6-дневная личинка, вид спереди, обозначены верхние (up) и нижние (lp) перикарии вентро-латеральных нервов орального поля; I - эпидермис апикальной пластинки у поздней гаструлы: все клетки имеют более менее сходную организацию, в некоторых из них обнаруживаются синаптические пузырьки (sv). Эпидермис подостлан слоем мезодермальных клеток (mc); J — эпидермис апикальной пластинки у 6-дневной личинки: клетки имеют разное тонкое строение. Показаны монополярные перикарии (то), биполярные или мультиполярные перикарии (bp), нейропиль (np), эпидермальные клетки (ec) и мезодермальные клетки (mc). Перикарий, имеющий форму колбы, обозначен наконечниками. Масштаб: I -2 мкм; J - 2,5 мкм. 
reactive neuritis is evident in the epidermis of the apical plate. Then first FMRFamide-reactive perikarya originate on the dorso-lateral sides of the preoral lobe near the apical plate. Then these perikarya disappear in Ph. vancouverensis (Hay-Schmidt, 1990a) and increase in number in Ph. harmeri (own data). According to Hay-Schmidt (1990a), older Ph. vancouverensis larvae lack FMRFamide-reactive perikarya, and the FMRFamide nervous system consists of the central neuropil and several "nerves" (neurite bundles): the median processes, posterolateral processes, the two bundles of the preoral lobe margin processes, the minor nerve ring, major nerves of collar region, and the posterior nerve ring around the anus.

All these neurite bundles were found in $\mathrm{Ph}$. harmeri larvae during our investigation. According to our data, however, Ph. harmeri larvae have numerous FMRFamide-reactive perikarya in the apical organ, in the epidermis of the preoral lobe, in the epidermis of the ventral and ventro-lateral sides of the oral field (collar region), and in the epithelium of the esophagus and the midgut. In the apical organ of older larvae, FMRFamide-reactive perikarya form two dorso-lateral groups of monopolar and multi- or bipolar neurons. Perikarya scattered in the epithelium of the preoral lobe and their processes contact with the marginal nerve of the preoral lobe and with the apical organ. In the epithelium of the esophagus, perikarya are located in the dorsal wall and form circular processes, which extend around the esophagus and cardiac sphincter. In the midgut, about 10 perikarya form a nerve ring near the pyloric sphincter. In the epidermis of the oral field, perikarya form five groups: upper left and right, lower left and right, and medioventral. The last is the most interesting because it has not been described before. Six-day-old larvae have a medioventral nerve cord, which extends from the oral nerve ring to the tentacular neurite bundle. The cord is composed of six bipolar perikarya, which are connected each other via thin longitudinal neurites (see Temereva, 2012). Nine-day-old larvae have two ventro-lateral nerves containing paired perikarya that are connected by thin commissures.
The ultrastructure of the nerve cells changes greatly during development. In later gastrula stages, the nerve cells of the apical organ resemble the common epidermal cells of the apical plate (Fig. 9I). The size and shape of the cell body and nucleus are similar for both kinds of cells. The main difference is that the cytoplasm rarely contains synaptic vesicles in nerve cells but never contains synaptic vesicles in epidermal cells (Fig. 9I). In 6-day-old larvae, the apical plate is composed of common epidermal cells and specialized perikarya (Fig. 9J). Neurites form a large neuropile under the cell bodies.

As shown before (see Hay-Schmidt, 1990; Santagata, 2004), in actinotrochs, the apical organ is composed of several types of perikarya (Fig. 9A). First, the apical plate contains a row of cells that are located along the anterior edge of the apical plate and in a horseshoe-shaped pattern. These cells have long, thick microvilli, which contain actin filaments that are stained by phalloidin. Long, thick microvilli are characteristic of the sensory cells of tentacles, and we can conclude that the cells of the apical plate are also sensory. These are ciliate cells, and they contain at least one striated rootlet, which passes near the nucleus (Fig. 9B). A round nucleus is situated basally and has light karyoplasm. Second, monociliated epithelial cells are located in the center of the apical plate above the neuropil (Fig. 9C). These cells have a wide apical part, which contains an elongate nucleus, and a thin and long basal part - axon. Third, the apical plate contains two groups of perikarya, one in the upper portion and the other in the basal portion (Fig. 9D). A layer of neurites separates these two groups of perikarya (Fig. 9D). The apical borders of the first group of perikarya (probably monopolar) bear thin microvilli and are in contact with the surrounding medium. The perikarya of the second group (probably bipolar or multipolar) rest on the basal lamina and contact the coelothelial cells of the preoral coelom; they do not have microvilli and do not contact the surrounding medium, even though the basal apparatus of the cilium occurs near the nucleus. This apparatus contains two centrioles, a striated rootlet, and an adjacent 
Golgi apparatus (Fig. 9E). The presence of the basal apparatus of the cilium is the evidence of appearance of perikarya of the second group from ciliate perykaria of first group during their plunge into the epidermis of the apical plate (our unpublished data). The neuropil of the apical organ is composed of numerous neurites, which contain various kinds of synaptic vesicles (Fig. 9C). Large neurites have less dense cytoplasm than small neurites. Marginal nerves of the preoral lobe pass between the basal parts of the epidermal cells of the preoral ciliated band. TEM reveals three bundles of neurites, which are separated by thin basal processes of epidermal cells (Fig. 9F). The median nerve passes between the apical organ and the marginal nerve. As shown by CLSM on early larvae, the middle part of the median nerve forms a bulge, which corresponds to the frontal organ of the older larva. This bulge, which is also revealed by TEM (Fig. 9G), resembles a large bundle of neurites, which rest on the basal lamina and are bordered by the thin epidermis of the preoral lobe. The tentacular nerve is located at the base of tentacular ridge. The neurites of the tentacular nerve pass near sensory cells, which bear long, thick microvilli (Fig. 9H). On its basal side, the tentacular nerve borders the basal lamina and contacts the circular muscle of the tentacles. Large perikarya and neurites occur in the epidermis of the esophagus (Fig. 9I). These neurons form the oral nerve ring. Most of these neurons are monopolar. Within each neuron, a roundish nucleus is situated basally and contains a nucleolus (Fig. 9I). The cytoplasm of these neurons contains numerous vesicles and appears less dense than the cytoplasm of adjacent cells. Neurites contact the basal lamina. Some neurites are very large (600-700 $\mathrm{nm}$ in diameter). The cytoplasm of neurites contains many synaptic vesicles of the first kind and few dense core vesicles. Perikarya and neurites are present on the epithelium of the cardiac sphincter. These neurites are up to $1 \mu \mathrm{m}$ in diameter. In the midgut, there are many basal neurites, which contain many kinds of synaptic vesicles (Fig. 9J). We did not find any cell bodies that could be regarded as perikarya. The epithelium of the proctodaeum is formed by cells that also contain many different kinds of vesicles (Fig. 9K). The nature of these vesicles is unknown, but their position in the apical cytoplasm and the CLSM data (the presence of signal in the apical portion of the proctodaeim epithelium) suggest that these vesicles may contain neurotransmitters. In addition, the basal processes occur near the basal lamina of the proctodaeum (Fig. 9L). These processes contain vesicles with electron dense material and are in close contact with the coelothelial cells of the trunk coelom.

According to our data, Ph. harmeri at early stages of development has a more complicated nervous system than other phoronid species. The presence of the ventral nerve cord is the most interesting feature of nervous system organization in Ph. harmeri and may reflect some evolutionary steps in the formation of the phoronid nervous system (Temereva, 2012). In phoronid larvae, the ventral nerve cord exhibits metamery because it is composed of repetitive perikarya and commissures. Phoronids may have inherited this nerve cord from an ancestor that is common to all bilaterian animals and that had a metameric organization. The presence of the metameric nerve cord supports the idea of metamery in phoronids (see Temereva, Malakhov, 2011b)

\subsubsection{Excretory system}

The development and anatomy of the phoronid excretory system was reported in our previous work with $P$ h. harmeri larvae (Temereva, Malakhov, 2006c).

In $P h$. harmeri, protonephridia appear in preactinotrocha as an unpaired ectodermal invagination, which is located in front of the anus and intestine (Fig. 10A). The protonephridial channels can be recognized by CLSM because the epithelium of the channel forms numerous long microvilli that contain actin fibres that can be stained by phalloidin (Fig. 10D-G). In early larval stages, the protonephridial complex consists of a large base and two branches (left and right), each of which bears one group of terminal cells (Fig. 10B, D). Each branch extends 


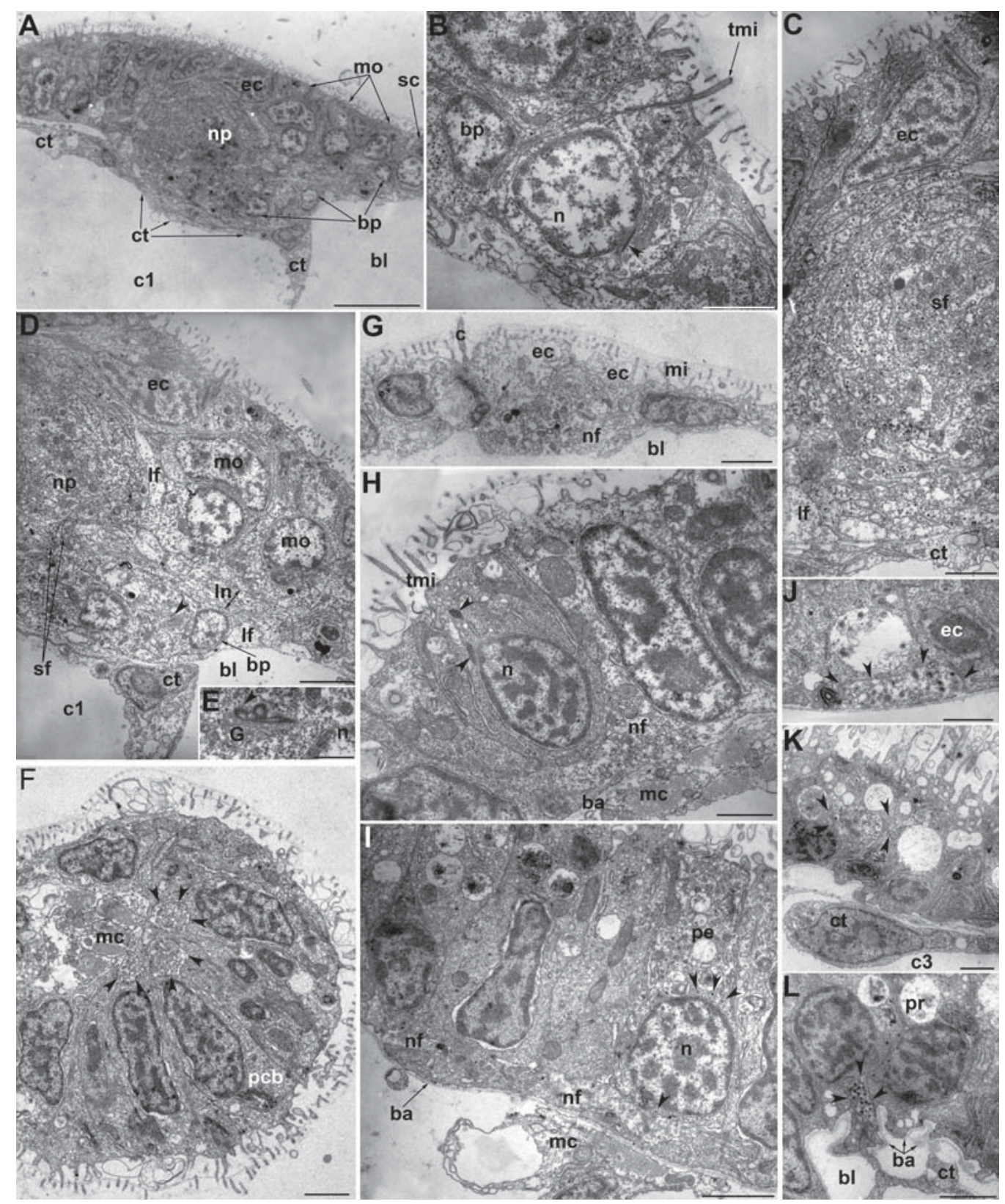

Fig. 9. Ultrastructure of some nerve elements in 13-day-old larva Phoronopsis harmeri, longitudinal sections.

A - general view of apical organ on parasagittal section, anterior point of preoral lobe is to the right, dorsal body side is to the left; apical point is at the top. The neuropil (np) occupies most of the apical organ; perikarya form two groups: upper (mo) and lower (bp). Sensory cells (sc) are located anteriorly; unspecialized epidermal cells (ec) are situated dorsally. Coelothelial cells (ct) of preoral coelom (c1) lay under neuropil and lower group of perikarya. Spacious blastocoel (bl) is located anteriorly; B - organization of sensory cell of apical organ showing thick microvilli (tmi), roundish nucleus (n), striated rootlet (arrowhead), and one perikaryon from lower group (bp). Anterior point of preoral lobe is to the right; dorsal body side is to the left; apical point is at the top; $\mathrm{C}$ - neuropil of apical organ consists of nerve fibers with large (lf) and small (sf) diameters. Top of neuropil is covered by epidermal cells (ec), and the bottom is covered 
along the lateral body walls and skirts the intestine (Fig. 10E). In 3-day-old larvae, the base of the protonephridial complex becomes thinner (Fig. 10E), and the left and right pritonephridia start to separate (Fig. 10F). In 5-day-old larvae, each protonephridium consists of a straight channel and 15-20 terminal cells (Fig. 10C). In more advanced larvae, the straight channel curves

by coelothelial cells (ct); D - anterior portion of apical organ, anterior point of preoral lobe is to the right, dorsal body side is to the upper left, apical point is at the top. Upper (mo) and lower (bp) groups of perikarya are separated by a layer of neurites $(\mathrm{ln})$. Basal body in perikaryon from lower group is indicated by arrowhead. Micrograph also shows part of neuropil (np) with large (lf) and small (sf) neurites, epidermal cell (ec), preoral coelom (c1) with lining (ct), and blastocoel (bl); E - basal apparatus (arrowhead) of rudimentary cilium, Golgy apparatus (G), and part of nucleus (n) in cytoplasm of pericaryon from lower group; F - sagittal section of the preoral lobe edge with ciliate cells of preoral ciliated band (pcb), muscle cells (mc), and three bundles of neurites (arrowheads). Anterior point is to the right; dorsal side is to the left; $\mathrm{G}$ - part of median nerve of preoral lobe. Concentration of neurites (nf) surrounded by basal lamina of blastocoels (bl) and epidermal cells (ec) with microvilli (mi) and cilia (c). Anterior point is to the right; dorsal side is to the left; $\mathrm{H}$ - portion of tentacular nerve: bundle of neurites (nf) in contact with basal lamina (ba) and muscle cells (mc), and located near sensory cell, which is characterized by presence of thick microvilli (tmi), several striated rootlets (arrowheads), and denser karyoplasm of nucleus (n). Anterior pole of larva is to the left, and posterior pole is to the right; I - perikaryon (pe) in epithelium of esophagus has synaptic vesicles (arrowheads) and basal processes (nf), which spread on the basal lamina (ba) and underlined by muscle cells $(\mathrm{mc})$. Cardiac sphincter is to the right, vestibulum is to the upper left; J - nervous fiber (arrowheads) in the basal part of epithelium (ec) of the midgut; K — part of proctodaeum wall and portion of trunk coelom (c3) with coelothelial cells (ct). Arrowheads are indicate vesicles, which look like synaptic vesicles. Midgut is to the upper left, anus is to the right; L — basal parts of proctodaeum wall (pr) with basal process (arrowheads), which contain vesicles, underlined by basal lamina of blastocoels (bl), and contact coelothelial cells (ct) of trunk coelom. Scale bars: A $-10 \mu \mathrm{m} ; \mathrm{B}, \mathrm{C}, \mathrm{H}-1.25 \mu \mathrm{m} ; \mathrm{D}-2.5 \mu \mathrm{m} ; \mathrm{E}-0.5 \mu \mathrm{m} ; \mathrm{F}, \mathrm{G}, \mathrm{I}, \mathrm{K}, \mathrm{L}-2 \mu \mathrm{m} ; \mathrm{J}-1 \mu \mathrm{m}$.

Рис. 9. Ультраструктура некоторых элементов нервной системы у 13-дневной личинки Phoronopsis harmeri, продольные срезы.

А - общий вид апикального органа на парсагиттальном срезе, передний край преоральной лопасти - справа, дорсальная сторона тела - слева. Нейропиль (np) занимает больший объем апикального органа; перикарии формирую две группы: верхнюю (pe1) и нижнюю (pe2). Чувствительные клетки (sc) располагаются впереди, неспециализированные эпидермальные клетки (ec) - сзади. Клетки выстилки (ct) предротового целома (c1) лежат под нейропилем и нижней группой перикариев. Обширный бластоцель (bl) занимает пространство спереди; В - организация чувствительной клетки апикального органа; показаны толстые микроворсинки (tmi), округлое ядро (n), исчерченный корешок (указан наконечниками) и один перикарион из нижней группы (ре2); $\mathrm{C}$ - нейропиль апикального органа образован нервными волокнами большого (lf) и маленького (sf) диаметров. С верхней стороны нейропиль покрыт эпидермальными клетками (ec), а с нижней - подостлан целотелиальными клетками (ct); D - передняя часть апикального органа. Верхняя (pe1) и нижняя (ре2) группы перикариев разделены слоем нервных волокон $(\ln )$. Базальное тело в цитоплазме перикариона нижней группы указано наконечником. На микрофотографии так же обозначены: часть нейропиля (np) с нервными волокнами большого (lf) и маленького (sf) диаметров, эпидермальные клетки (ec), предротовой целом (c1) и клетки выстилки (ct) и бластоцель (bl); E - участок цитоплазмы перикариона нижней группы. Показаны: базальное тельце (наконечник) рудиментарного жгутика, аппарат Гольджи (G) и часть ядра (n); F — сагиттальный срез края преоральной лопасти со жгутиковыми клетками преорального ресничного шнура (pcb), мышечными клетками (mc) и тремя пучками нервных волокон (указаны наконечниками); $\mathrm{G}$ - часть медиального нерва преоральной лопасти: скопление нервных волокон (nf) окружено базальной пластинкой бластоцеля (bl) и эпидермальными клетками (ec) с микроворсинками (mi) и жгутиками (c); Н - участок щупальцевого нерва: пучок нервных отростков, контактирующие с базальной пластинкой (ba) и мышечными клетками (mc)и проходящий рядом с сенсорными клетками, которые характеризуются наличием толстых микроворсинок (tmi), нескольких исчерченных корешков (указаны наконечниками) и плотной кариоплазмой ядра (n); I — перикарион (pe) в эпителии пищевода содержит синаптические пузырьки (указаны наконечниками) и имеет базальные отростки (nf), распластанные по базальной пластинке (ba), к которой с другой стороны прилежат мышечные клетки (mc). Кардиальный сфинктер - справа, вестибулюм - сверху; J - нервные волокна (указаны наконечниками) в базальной части эпителия средней кишки; K - участок эпителия задней кишки и участка туловищного целома (c3) и его выстилки (ct). Наконечниками указаны везикулы, которые выглядят сходно с синаптическими пузырьками. Средняя кишка в верхнем левом углу, анус - справа; L — базальная часть стенки задней кишки (pr) с базальными отростками (указаны наконечниками), которые содержат везикулы, подостланы базальной пластинкой бластоцеля (bl) и контактируют с целотелиальными клетками (ct) туловищного целома. Масштаб: А - 10 мкм; В, С, Н-1,25 мкм; D-2,5 мкм; $\mathrm{E}-0,5$ мкм; F, G, I, K, L - 2 мкм; J - 1 мкм. 

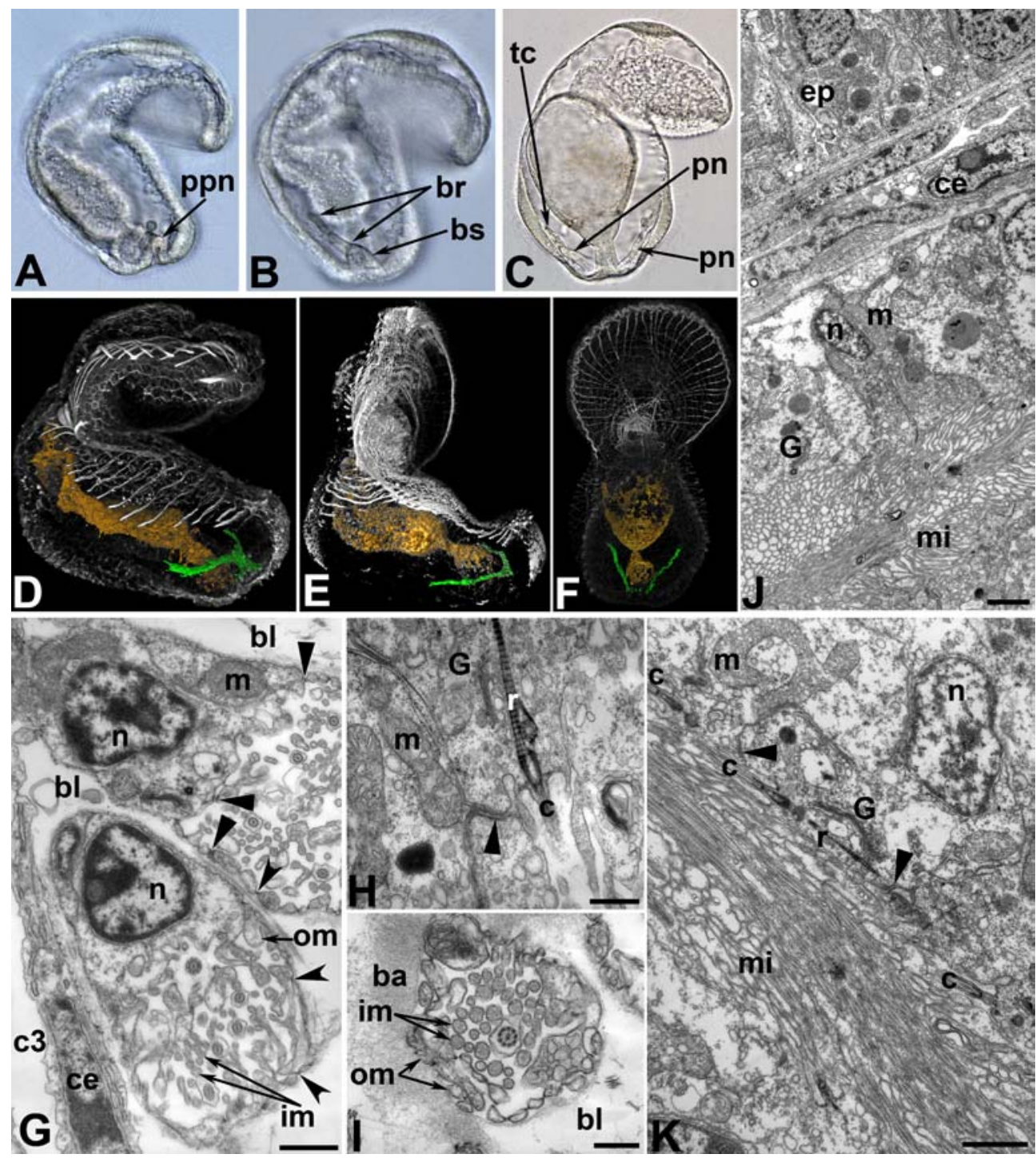

Fig. 10. Development and organization of protonephridia in Phoronopsis harmeri larvae. A-C photographs of live animals; D-F - 3D-reconstructions made with Amira ver. 5.2.2. The top of the organism is oriented to the top of each photographs. The protonephridia are indicated by green; the gut - by dark yellow; the muscles and actin containing structures - by grey. G-K - transmission electron microscopy (TEM), micrographs, longitudinal sections of larvae, desmosomes are indicated by straight arrowheads, electron-dense contacts are indicated by concave arrowheads.

A - lateral view of preactinotrocha with ventral ectodermal primordium of the protonephridia (ppn); B - lateral view of an early larval stage with protonephridial complex: basis (bs) and branches (br); C - ventro-lateral view of a 5-dayold larva with two separated protonephridia (pn), each of which bears terminal cells (tc); D - lateral view of an early actinotrocha; E - Lateral view of a young actinotrocha; $\mathrm{F}$ - dorsal view of a 5-day-old actinotrocha; $\mathrm{G}$ - Terminal cells (nucleus (n), mitochondria (m), inner microvilli (im), and outer microvilli (om)) are located in blastocoel (bl) near the coelomic lining (ce) of the trunk coelom (c3); H - the apical surface of the terminal cell with cilium (c), striated rootlet (r), Golgi apparatus $(\mathrm{G})$, and large mitochondria $(\mathrm{m})$; I - cross section through the collar region of one terminal cell showing the inner microvilli (im), outer microvilli (om), basal lamina (ba), and blastocoel (bl); J - the wall of excretory channel, which contacts with two layers of coelomic lining (ce). The lumen of the channel is filled with cilia 
and consists of two branches: a shorter, ascending branch and a longer, descending branch (see Temereva, Malakhov, 2006). The descending branch extends between two coelothelial layers: mesocoel lining and metacoel lining (Fig. 10G, J). Thus, the descending branch is situated inside the diaphragm. The ascending branch is located more ventrally than the descending branch and opens by the nephridiopore on the lateral side under the tentacles. The number of terminal cells then increases to as many as 40 . The terminal cells are exposed in spacious blastocoels above the tentacles and form an upper group. In competent larvae, the lower group of terminal cells appears and is located between the body wall and coelothelial lining of the trunk coelom. Here, the large blastocoel forms between the body wall and coelomic lining, which is $100-150 \mu \mathrm{m}$ distant from the body wall. The lower group consists of 20 terminal cells. Thus, in $P h$. harmeri larvae, each protonephridium has two terminal parts with 40-50 terminal cells in the upper part and 20 terminal cells in the lower part. Interestingly, there are some differences among descriptions of terminal-part organization. Thus, Hay-Schmidt (1987) found 25 terminal cells in the protonephridia of Acti- notrocha branchiata Mueller 1846 (larva of Ph. muelleri); each of these cells directly contacts the channel. In contrast, Bartolomaeus (1989) studied larvae of the same species ( $P h$. muelleri) and recognized three terminal aggregations, each of which consists of 30 terminal cells and 15 accessory cells; the terminal portion of each protonephridium contains 125 cells: 45 accessory cells and 90 terminal cells. In the creeping lecititrophic larvae of $\mathrm{Ph}$. ovalis, each protonephrida consists of an excretory channel, five terminal cells, and one accessory cell (Grobe, Bartolomaeus, 2007).

The histology and ultrastructure of protonephridia in different phoronid species have been described by various authors (Selys-Longchamps, 1902; Menon, 1902; Goodrich, 1903; Shearer, 1906; Hay-Schmidt, 1987; Bartolomaeus, 1989). All of these descriptions were made on larvae of Phoronis spp. Here, we present new data about the ultrastructure of the protonephridia in advanced larvae belonging to other genera - Phoronopsis (Ph. harmeri).

The separate terminal cell is monociliate and cylindrical (Fig. 10G, H). The apical surface bears one cilium and two kinds of microvilli. The outer microvilli are thick and form a collar

and microvilli (mi). Nucleus (n), mitochondria (m), epidermis (ep), and Golgi apparatus (G) are indicated; K — a portion of the lumen of the excretory channel showing cilia (c), striated rootlet (r), nucleus (n), mitochondrion (m), and microvilli (mi). Scale bars: $\mathrm{G}, \mathrm{K}-1 \mu \mathrm{m} ; \mathrm{H}-0.7 \mu \mathrm{m} ; \mathrm{I}-0.5 \mu \mathrm{m} ; \mathrm{J}-1.3 \mu \mathrm{m}$.

Рис. 10. Развитие и организация протонефридиев у личинки Phoronopsis harmeri. A-C — фотографии живых личинок; D-F - 3D-реконструкции, сделанные в программе Amira вер. 5.2.2. Передний конец тела животных ориентирован строго вверх. Протонефридии обозначены зеленым цветом, кишечникжелтым, мышцы и актинсодержащие структуры — серым; G-K — трансмиссионная электронная микроскопия (TEM), микрофотографии; продольные срезы; десмосомы указаны прямыми наконечниками; электронно-плотные контакты указаны вогнутыми наконечниками.

А - преактинотроха с вентральным непарным эктодермальным зачатком протонефридиев (ppn); вид сбоку; B - ранняя личинка (вид сбоку) с протонефридиальным комплексом: непарное основание (bs) и две латеральные ветви (br); C - вентро-латерально 5-дневная личинка с двумя разделившимися протонефридиями (pn), каждый из которых несет терминальные клетки (tc); D - ранняя актинотроха сбоку; Е — молодая актинотроха сбоку; F - вид с сади, 5-дневная личинка; G - терминальные клетки (ядро (n), митохондрии (m), внутренние микроворсинки (im), внешние микроворсинки (om)) располагаются в бластоцеле (bl) рядом с целомической выстилкой (се) туловищного целома (c3); Н - апикальная часть терминальной клетки со жгутиком (c), исчерченным корешком (r), аппаратом Гольджи (G) и крупной митохондрией (m); I — поперечный срез через воротничок терминальной клетки, показаны внутренние микроворсинки (im), внешние микроворсинки (om), базальная пластинка (ba) и бластоцель (bl); J - стенка выделительного канала в месте контакта с целомической выстилкой (се), прилежащей к эпидермису (ер) стенки тела. Просвет канала заполнен жгутиками и микроворсинками (mi). Отмечены: ядро (n), митохондрии (m) и комплекс Гольджи (G); K - участок просвета выделительного канала, показаны жгутики (c), исчерченные корешки (r), ядра (n), митохондрии (m), микроворсинки (mi). Масштаб: G, $\mathrm{K}-1$ мкм; $\mathrm{H}-0,7$ мкм; I - 0,5 мкм; J - 1,3 мкм. 
along the cell periphery (Fig. 10I). The inner microvilli are thinner and located in the centre near the cilium. The cytoplasm differs in these two kinds of microvilli: the cytoplasm is electron lighter and contains many vesicles in the outer microvilli but is denser and never contains vesicles in the inner microvilli. The outer microvilli bear desmosomes, contact each other via desmosomes and special electron-dense contacts, and form a tube that surrounds the cilium and inner microvilli (Fig. 10G). Externally, this tube is covered by a thick layer of the basal lamina, which contains long collagenous fibres and forms a filter for ultrafiltration (Fig. 10I). The cell body contains the basal apparatus of the cilium, which consists of the basal body, accessory centriole, long vertical rootlet, Golgi apparatus, nucleus, and large mitochondria (Fig. $10 \mathrm{H})$. We did not find accessory cells in the terminal parts of phoronid protonephridia. According to Bartolomaeus (1989), the organization of accessory cells is similar to that of terminal cells, but their cilia expose into blastocoels instead of the excretory channel.

The excretory channel is composed of monociliate cells (Fig. 10J, K). The undulipodium, basal body of cilium, and striated rootlet are situated parallel to the apical surface (Fig. 10K). The striated rootlet bears numerous microvilli, which fill the lumen of the channel. Between bases of adjacent microvilli, absorption occurs and vesicles arise. The apical cytoplasm contains many vesicles of different sizes. The nucleus occupies the basal part of the cell. Mitochondria and rough endoplasmic reticulum are concentrated in the basal cytoplasm but are also present in the apical cytoplasm (Fig. 10J, K).

The protonephridia of Ph. harmeri larvae have an organization that is typical for phoronid larvae and for some trochophores and adult annelids. In phoronids, the protonephridium contains many terminal cells, which have only one cilium, whereas in the most species of annelids, each protonephridium bears from one to three terminal cells, which usually have several ciliary elements (Bartolomaeus, Quast, 2005). The organization of phoronid protonephridia indicates that they are the most primitive type of protonephridia among all Bilateria. The functional organization of the protonephridia was described by Smith and Ruppert (1988). The organization of the protonephridia in phoronids and their position in blastocoels between thick layers of basal lamina is consistent with a role in ultrafiltration in that the basal lamina together with the outer microvilli form a filter, and the cilium creates pressure inside the collar of the terminal cell. The presence of many vesicles in the cytoplasm of excretory channel cells indicates that this area functions in absorption.

\subsection{Entoblast}

Most parts of the digestive tract arise from the entoblast. The trunk coelom can also be regarded as derived from the entoblast because it arises from the larval gut.

\subsubsection{Digestive system}

The anatomy and ultrastructure of the larval digestive tract in phoronids were studied in our previous works (Temereva, Malakhov, 2007; Temereva, 2010). Here, we briefly describe the formation and organization of the digestive tract at early stages of $P h$. harmeri development.

The archenteron forms as an invagination of the vegetal pole of the blastula. In the middle gastrula stage, it has a round terminal end and looks like a sack, which occupies most of the blastocoel but which does not contact the ectoderm of the posterior pole (Fig. 11A). Then, in the late gastrula stage, the archenteron is elongated because the posterior cone-shaped portion appears (Fig. 11B). This portion of the archenteron will eventually give rise to the midgut. Later, the form of the embryo changes: the mouth deepens, and the precursor of the esophagus forms (Fig. 11C). At the same time, the posterior end of the archenteron forms a small terminal bulge directed towards the ectoderm (Fig. 7A, ei). A counter-directed shallow ectodermal depression forms concurrently. The two structures merge to form a complete 


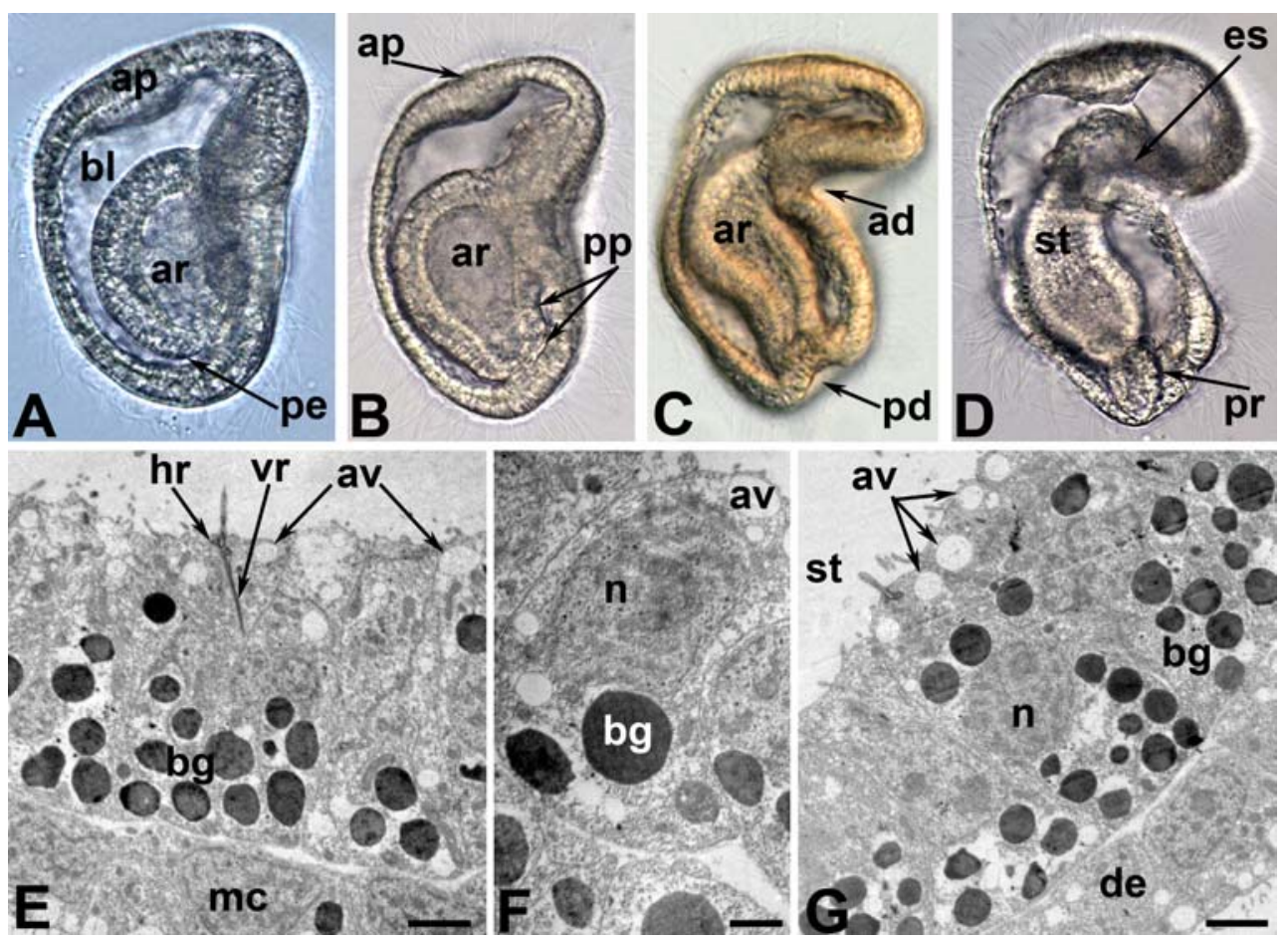

Fig. 11. Development and organization of the digestive tract in Phoronopsis harmeri. A-D - photographs of live animals. Lateral view, the ventral side is on the right, the anterior pole is at the top; $\mathrm{E}-\mathrm{G}-$ micrographs of the digestive epithelium in an early larval stage.

A - middle gastrula stage with round posterior end (pe) of archenteron (ar), spacious blastocoel (bl), and apical plate (ap); B - later gastrula stage with cone-shaped posterior portion (pp) of the archenteron (ar) and the apical plate (ap); $\mathrm{C}$ - a preactinotrocha with an elongated archenteron (ar) and anterior (ad) and posterior depressions (pd) of the ectoderm; D - early larval stage with esophagus (es), stomach (st), and proctodaeum (pr); E - fine structure of the upper wall of the esophagus showing the horizontal rootlet (hr), vertical rootlet (vr), apical vacuoles (av), basal granules (bg), and adjacent mesodermal cells $(\mathrm{mc}) ; \mathrm{F}$ - a cell of the ventral wall of the stomach with central nucleus (n), apical vacuoles (av), and basal granules (bg); G - the dorsal wall of the stomach (st) borders the dorsal epidermis (de). Scale bars: E, $\mathrm{G}-2 \mu \mathrm{m} ; \mathrm{F}-1 \mu \mathrm{m}$.

Рис. 11. Развитие и организация пищеварительного тракта Phoronopsis harmeri. A-D — фотографии живых животных. Вид сбоку, вентральная сторона справа, передний конец тела - сверху; $\mathrm{E}-\mathrm{G}-$ тонкое строение отделов пищеварительного тракта ранней личинки.

A - средняя гаструла с округлым задним концом (pe) архентерона (ar), обширным бластоцелем (bl) и апикальной пластинокй (ap); В - поздняя гаструла с коническим задним концом (pp) архентерона (ar) и апикальной пластинкой (ap); C - преактинотроха с вытянутым архентероном (ar), а так же передним (ad) и задним (pd) углублениями эктодермы; D — ранняя личинка с пищеводом (es), желудком (st) и задней кишкой (pr); E - тонкое строение эпителия верхней стенки пищевода, показаны горизонтальный (hr) и вертикальный (vr) исчерченные корешки, вакуоли в апикальной цитоплазме (av), гранулы в базальной цитоплазме (bg) и прилежащие мезодермальные клетки (mc); F — клетка вентральной стенки желудка с центральным ядром (n), вакуолями в апикальной цитоплазме (av) и гранулами в базальной цитоплазме (bg); G - дорсальная стенка желудка, граничащая с эпидермисом (de) дорсальной стороны тела. Масштаб: E, G -2 мкм; F -1 мкм.

intestine (Fig. 11D). Thus, the proctodaeum of $P h$. harmeri larva originates from the posterior ectoderm. This fact was metioned before in $P h$. ijimai (Freeman, Martindale, 2002).
In the preactinotrocha, the epithelium of the digestive tract is thick and has the same ultrastructure throughout (Fig. 7A) but there are differences in the size and shape of cells and 


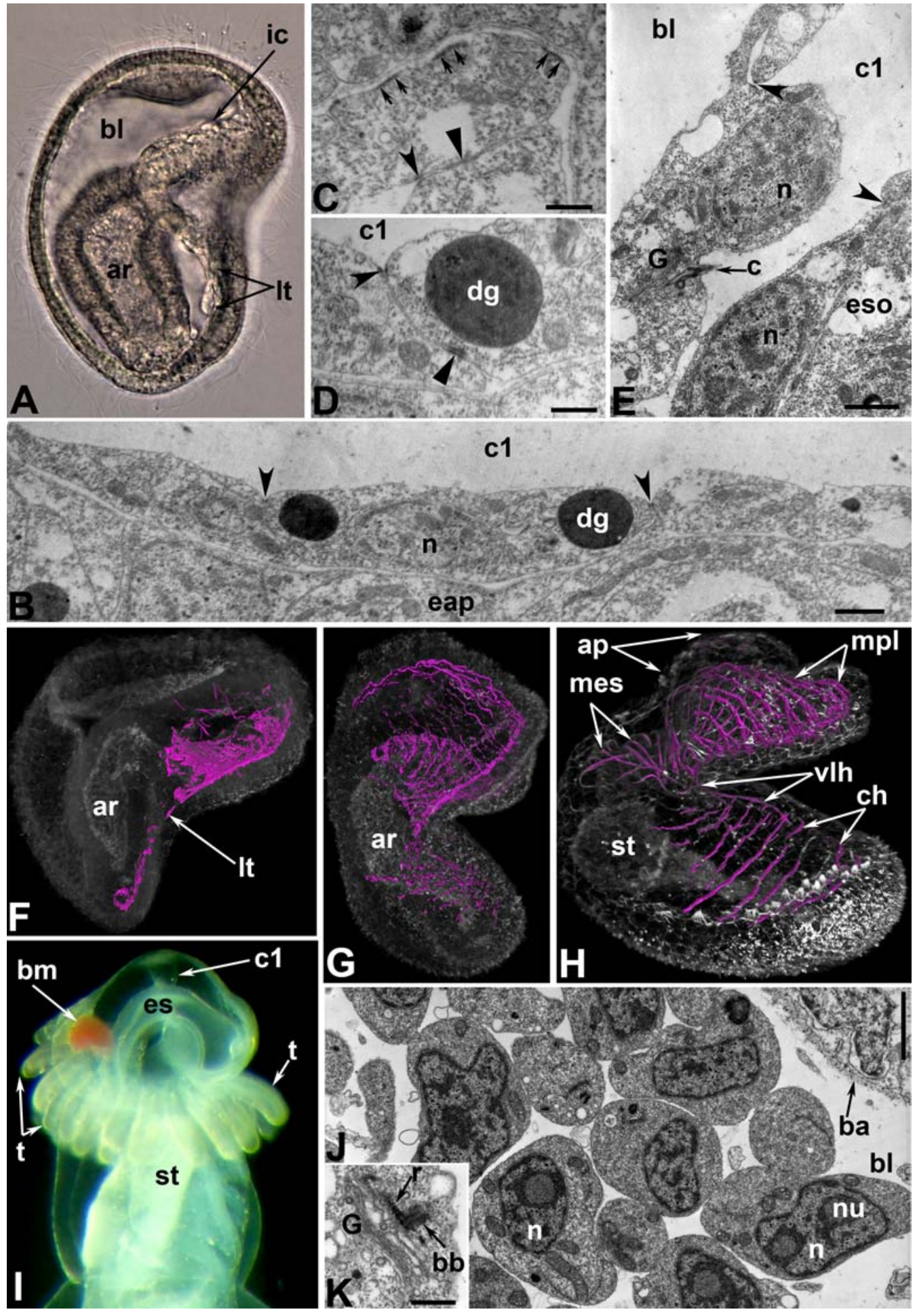


their nuclei (Fig. 11E-G). Thus, the epithelium of the esophagus near the mouth is composed of columnar cells with irregular nuclei, which occupy the middle or basal part of the cell (Fig. $11 \mathrm{E})$. Cuboudal cells with thin, rare microvilli and large round nuclei with nucleoli form the ventral wall of the stomach (Fig. 10F). The epithelium of the dorsal wall of the stomach is thicker than the epithelium in other areas; it is formed by cylindrical cells with round nuclei located in their middles (Fig. 11G). All epithelial cells are monociliate and contain large apical vesicles with transparent content and basal electron-dense granules (Fig. 11E-G). The apical cell surface forms short, sparse microvilli. The basal apparatus of the cilium consists of a basal body, accessory centriole, and two striated rootlets (short-horizontal and long-vertical).

In early larval stages, which start to feed, the digestive tract consists of five parts: the vestibu-

Fig. 12. Details of organization of mesodermal cells at different stages of development of Phoronopsis harmeri. A, I - photographs of live animals; B-E, J-K - micrographs of derivatives of mesodermal cells. Desmosomes are indicated by concave arrowheads, addition junctions are indicated by straight arrowheads, double arrows indicate hemidesmosomes; F-H - 3D-reconstructions of an embryo at different stages of development, made with Amira ver. 5.2.2. Lateral view, the anterior pole is at the top of the photographs, the ventral side is on the right. The muscular system is indicated by magenta, other actin-containing elements are indicated by grey.

A - lateral view of later gastrula stage with mesodermal cells (ic), spacious blastocoel (bl), archenteron (ar), and two ventro-lateral tiers (lt) of mesodermal cells; B - a portion of the mesodermal lining of the preoral coelom (c1) adjacent to the epidermis of the apical plate (eap). Mesodermal cells contain nuclei (n) and large electron-dense granules (dg); $\mathrm{C}$ - mesodermal cells near the epidermis of the preoral ciliated band; D - cells of the lower wall of the preoral coelom (c1); E - posterior portion of the preoral coelom (c1) near the epithelium of the esophagus (eso): the lining is formed by monociliate cells with cilium (c), Golgi apparatus (G), and nucleus (n); F - later gastrula stage with a small archenteron (ar), a continuous layer of muscle cells on the lower wall of the preoral lobe precursor, and lateral tiers (lt) of muscle cells; G - Preactinotrocha; H - early larval stage with a large apical plate (ap), stomach (st), well-developed muscles of the preoral lobe (mpl), circular muscles of the esophagus (mes), circular muscles of the hyposphere (ch), and two longitudinal ventro-lateral muscles of the hyposphere (vlh); I - larva with twelve pairs of tentacles. Lateral view showing mass of erythrocytes (bm), preoral coelom (c1), esophagus (es), stomach (st), and tentacles (t); J - the mass of erythrocytes in the blastocoel (bl) near the basal lamina (ba) of the epidermis. Nuclei (n) and nucleolei (nu) are indicated; $\mathrm{K}$ - a portion of the erythrocyte cytoplasm with striated rootlet (r), basal body (bb), and Golgi apparatus (G). Scale bars: B, E, $-1 \mu \mathrm{m} ; \mathrm{C}, \mathrm{D}, \mathrm{K}-0.5 \mu \mathrm{m} ; \mathrm{J}-2 \mu \mathrm{m}$.

Рис. 12. Деткали огранизации мезодермальных клеток на разных стадиях развития Phoronopsis harmeri. A, I - фотографии живых животных; В-E, J-K - микрофотографии потомков мезодермальных клеток. Десмосомы указаны вогнутыми наконечниками, дополнительные контакты - прямыми наконечниками, гемидесмосомы - двойными стрелками; F-H - 3D-реконструкции эмбрионов на разных стадиях развития. Выполнено в программе Аmira вер. 5.2.2. Вид сбоку, передний конец сверху, вентральная сторона - справа. Мускулатура обозначена пурпурным цветом, другие актинсодержащие структуры - серым цветом.

A — поздняя гаструла, вид сбоку. Показаны мезодермальные клетки (ic), обширный бластоцель (bl), архентерон (ar) и два вентро-латеральных ряда (lt) мезодермальных клеток; В - участок мезодермальной выстилки предротового целома (c1), прилежащий к эпидермису апикальной пластинки (еар). Мезодермальные клетки несут ядро (n) и крупные электронно-плотные гранулы (dg); C - мезодермальные клетки на поверхности эпидермиса предротового ресничного; D - клетки нижней стенки предротового целома (c1); $\mathrm{E}-$ задний участок предротового целома (c1) рядом с эпителием пищевода (eso): выстилка образована моноцилиарными клетками со жгутиком (c), комплексом Гольджи (G) и ядром (n); F- поздняя гаструла с маленьким архентероном (ar), сплошным слоем мышечных клеток на нижней поверхности зачатка преоральной лопасти и латеральными рядами (lt) мышечных клеток; $\mathrm{G}$ - преактинотроха; $\mathrm{H}$ - ранняя личинка с апикальной пластинкой (ap), желудком (st), хорошо развитой мускулатурой преоральной лопасти (mpl), кольцевой мускулатурой пищевода (mes), кольцевой мускулатурой гипосферы (ch) и двумя вентро-латеральными мышцами гипосферы (vlh); I личинка с 12 парами щупалец. Вид сбоку, показывающий скопление эритроцитов (bm), преоральный целом (c1), пищевод (es), желудок (st) и щупальца (t); J - скопление эритроцитов в бластоцеле (bl) вблизи базальной пластинки (ba) эпидермиса. Отмечены ядра (n) и ядрышки (nu); K - участок цитоплазмы эритроцита с исчерченным корешком (r), базальным тельцем (bb) и комплексом Гольжди (G). Масштаб: В, E, — 1 мкм; C, D, $\mathrm{K}-0,5$ мкм; J - 2 мкм. 
lum with the mouth, the esophagus with the cardiac sphincter, the stomach, the midgut, and the proctodaeum. The young actinotrocha has a differentiated digestive tract, but the ultrastructure is the same in different parts of digestive tract. In comparison with later gastrula stages, all cells of the digestive epithelium in young larval stages lack apical vesicles and basal electron-dense granules. In more advanced larval stages, the ultrastructure differs in different parts of the digestive tract. The epithelium of the esophagus becomes columnar and very thick, the epithelium of the stomach accumulates nutrients (lipid droplets and yolk granules) and the stomach diverticulum arises, the epithelium of the midgut becomes biciliate; and the proctodaeum subdivides into two parts. The anatomy and ultrastructure of digestive tract in competent actinotrochs were described in previous work (Temereva, 2010).

\subsection{Mesoblast}

The muscular system, coelomic system, and blood corpuscles arise from the mesoblast. The mesoblast (mesoderm) arises from two multicellular sources (see above) (Fig. 4B, 6A). Phoronid myogenesis had not been studied before. We have investigated consecutive stages of $P h$. harmeri and obtained data about myogenesis using confocal microscopy (CLSM) and transmission electron microscopy (TEM).

Coelothelial and muscle cells arise from one source, i.e., the mesoderm. In the middle gastrula stage, which has small archenteron and spacious blastocoel, the two kinds of cells have a similar ultrastructure for the first several days after they migrate from the anterior wall of the archenteron. After they migrate, the cells have a strong actin-myosin net under their surface and are stained by phalloidin. Immediately after migration, the cells rest on the basal lamina of the ectoderm and archenteron. They move from the anterior pole to the posterior portion of the embryo, skirt the oral opening, and form two ventro-lateral tiers along oral field (Fig. 12A). With time, most cells that migrated into the blastocoel transform into muscle cells. During the first 2 days after migration, there are no differences between the cells of the coelomic lining and muscle cells. These cells are flat and form long processes, which spread on the basal lamina (Fig. 12B). Round nuclei with nucleoli occupy the center of the cell. Myofilaments cannot be detected by TEM. In some muscle cells, a few electron-dense fibers occur in the basal cytoplasm. Some areas of the basal surface are more electron dense than adjacent areas: hemidesmosomes appear in these electrondense areas (Fig. 12C). Cells contact each other by lateral borders and connect via desmosomes, which are located near the apical surface (Fig. 12B-E). Additional cellular contacts sometimes occur between cells via additional desmosomes on the middle of the lateral borders (Fig. 12D) or via septate contacts (Fig. 12C). Mesodermal cells are underlained by basal lamina. Thus, the epithelium, which is formed by mesodermal cells, corresponds to true epithelium - coelothelium. The mesodermal cells that migrated from the archenteron form a large closed cavity in the precursor of the preoral lobe (Fig. 12E). This cavity can be regarded as a coelom because it is closed and lined with true epithelium. Like all other cells in early embryonic stages, the cells that migrated contain large electron-dense yolk granules and few apical vesicles with transparent content.

\subsubsection{Muscular system}

The phoronid muscular system begins to form when the embryo is 48-hours-old. The muscle cells differentiate from mesodermal cells, which have migrated into the blastocoel from the anterior wall of the archenteron. First, thin muscular fibers spread on the basal lamina of the preoral lobe precursor (Fig. 12F). These muscle fibers form a continuous layer on the lower wall and form a few bundles on the upper wall. Singular muscle fibers are evident in the hyposphere on the basal lamina of the oral field epidermis (Fig. 12F). Over several hours, the main muscles of the preoral lobe arise: thick marginal muscle originates on the edge of the preoral lobe, and radial muscles extend from the 
upper wall of the preoral lobe to the edge (Fig. $12 \mathrm{G})$. The continuous layer of muscle cells gives rise to the thick muscles of the esophagus (Fig. 12G, H). In the hyposphere, muscles first arise on the ventral side and form a circular musculature. With time, muscle cells lose connection and desmosomes disappear. Simultaneously, myofilaments arrange regularly, and striated muscle forms. The muscular system in young larvae consists of the marginal, radial, and circular muscles of the preoral lobe; the circular muscles of the esophagus, circular muscles of the hyposphere; and two ventro-lateral muscles, which correspond to two tiers of mesodermal cells (Fig. 12H).

\subsubsection{Coelomic system}

In young larvae, the coelomic system consists of one coelomic compartment - the preoral coelom. The preoral coelom is located in the preoral lobe under the apical plate and looks like a cylinder (Fig. 12I). In contrast to muscle cells, cells of the coelomic lining do not lose desmosomes, and they form true epithelium. The cytoplasm of coelomic cells lacks myofilaments and contains numerous tubes and vesicles of rough endoplasmic reticulum. A nucleus with nucleolus occupies the centre of the cell. The mature larva has three coelomic compartments, the organization of which is described in detail in our previous work (Temereva, Malakhov, 2006c).

\subsubsection{Blood system}

The blood system is a blastocoel, which is derived from the blastula and occurs as a net of slits between epitheliums. Primarily, the wall of the blood vessel is the basal lamina of the blastocoel and contains amorphous material and collagenous fibres. Blood corpuscles arise from and differentiate from nonspecialized mesodermal cells, which arise from the anterior mesodermal precursor. In phoronids, there are two sorts of blood corpuscles: erythrocytes and amoebocytes. In Ph. harmeri, erythrocytes can first be found in larvae with five pairs of tenta- cles. Erythrocytes form two groups in the blastocoel of the collar region (between the tentacles and the preoral lobe) (Fig. 12I). Erythrocytes are usually round. They closely contact each other and the basal lamina of the blastocoel (Fig. 12J). The nucleus in erythrocytes is large and bears a nucleolus (Fig. 12J). A rudimentary cilium (basal-body and striated-rootlet cilia associated with the Golgi apparatus) occurs in the cytoplasm of the erythrocyte (Fig. 12K). The cilium is inherited from ciliate cells of the anterior wall of the archenterion, which give rise to the anterior mesoderm. The organization of the blood system in phoronid larvae was described in our previous work (Temereva, Malakhov, 2000).

\section{Conclusion}

Phoronids combine features of the Protostomia and Deuterostomia and demonstrate some plesiomorphic features of development and organization. First, egg cleavage of phoronids can be regarded as transitory between typical radial and typical spiral cleavage. The presence of oblique furrows in early phoronid development should not be interpreted to mean that phoronid cleavage is typical radial. At the same time, phoronids lack a specific mosaic of blastomeres, the presence of which is a characteristic of true spiral development. Phoronids also lack trochoblasts, rosettes, and cross cells. Two sources of the coelomic mesoderm, which are well pronounced in phoronids, were found in all of the main groups of Bilateria. This dual mesoderm formation seems to be a plesiomorphic feature inherited from a common bilaterian ancestors. Second, the activity of ciliated bands in phoronid larvae combines features of the Protostomia and Deuterostomia. In actinotrocha, the preoral ciliated band works as it does in protostomian larvae (the preoral ciliated band beats from anterior to posterior), whereas the postoral ciliated band works as it does in deuterostomian larvae (the postoral ciliated band beats from anterior to posterior). Third, development of the nervous system in phoronids begins in the apical pole, and at least 25 monopolar serotonergic 
perikarya differentiate in the epidermis of the apical plate. The large number of neurons and their position in the apical organ are more typical for deuterostomian larvae (e.g., for tornaria larva) than for trochozoan larvae. At the same time, the flask-shaped serotonegric perikarya are more typical for protostomian larvae. We can conclude that phoronid neurogenesis is also transitory in that it combines protostomian and deuterostomian characteristics. The same mixture of protostome and deuterostome developmental traits is known in mitraria larva of Owenia collaris Chiaje 1841 (Smart, Dassow, 2009).

Overall, that developmental data corroborate the protostomian affinity of phoronids. At the same time, phoronids retain some plesiomorphic features of organization and development that indicate their basal position within the lophotrochozoan clade.

\section{Acknowledgments}

Elena Temereva is very grateful to her friends Svetlana Maslakova and Gorge von Dassow (OIMB, OR, USA) for their help in obtaining interesting material about phoronid development. ENT is also grateful to Thomas Schwaha and Stephan Handschuh (Univ. Vienna, Austria) for helping her with the Amira program. We thank B. Jaffee for help with the English language. The project was funded by the Russian Foundation for Basic Research (11-04-00690), the Ministry of Education and Science of Russian Federation (contracts \#P727,\#02.740.11.0875), and Grant of the President of Russian Federation (MD-2892.2011.4). The participation of Vladimir Malakhov was supported by the Grant of the Government of Russian Federation No. 2010220-01-180.

\section{References}

Ax P. 2001. Das System der Metazoa III. Ein Lehrbuch der phylogenetischen systematic. Spektrum, Heidelberg. Germany: Gustav Fischer Verlag. P.1-384.

Bartolomaeus T. 1989. Ultrastructure and relationship between protonephridia and metanephridia in Phoronis muelleri (Phoronida) // Zoomorphol. Vol.109. P.113-122.
Bartolomaeus T. 2001. Ultrastructure and formation of the body cavity lining in Phoronis muelleri (Phoronida, Lophophorata) // Zoomorphol. Vol.120. P.135-148.

Bartolomaeus T., Quast B. 2005. Structure and development of nephridial in Annelida and related taxa // Hydrobiologia. Vol.535/536. P.139-165.

Bassham S., Postlethwait J. 2000. Brachiury (T) expression in embryos of a larvacean urochordate, Oikopleura dioica, and the ancestral role of $\mathrm{T} / /$ Dev. Biol. Vol.220. P.322-332.

Beklemishev V.N. 1964. [Principles of Comparative Anatomy of Invertebrates.] Moscow: Sovetskaya Nauka. Vols 1, 2. [in Russian]

Boyer B.C., Henry J.J., Martindale M.Q. 1998. The cell lineage of a polyclad turbellarian embryo reveals close similarity to coelomic spiralians // Dev. Biol. Vol.204. P.111-123.

Brooks W.K., Cowles R.P. 1905. Phoronis architecta: its life history, anatomy and breeding habits // Mem. Nation. Acad. Sci, Washington. Vol.10. P.72-113.

Bullivant J.S. 1968. The method of feeding of Lophophorates (Bryozoa, Phoronida, Brachiopoda) // N.Z. J. Mar. Freshw. Res. Vol.2. P.135-146.

Cohen B.L. 2000. Monophyly of brachiopods and phoronids: reconciliation of molecular evidence with Linnaean classification (the subphylum Phoroniformea nov.) // Proc. R. Soc. B. Biol Sci. Vol.267. P.225-231.

Cohen B.L., Gawthrop, A.B., Cavalier-Smith T. 1998. Molecular phylogeny of brachiopods and phoronids based on nuclear-encoded small subunit ribosomal RNA gene sequences // Phil. Trans. Roy. Soc. Lond. B. Vol.353. P.2039-2061.

Cohen B., Weydmann A. 2005. Molecular evidence that phoronids are a subtaxon of brachiopods (Brachiopoda: Phoronata) and that genetic divergence of metazoan phyla began long before the early Cambrian // Org. Divers. Evol. Vol.5. P.253-273.

Dunn C.W., Hejnol A., Matus D.Q., Pang K., Browne W.E., Smith S.A., Seaver E., Rouse G.W., Obst M., Edgecombe G.D., Sørensen M.V., Haddock S.H.D., Schmidt-Rhaesa A., Okusu A., Kristensen R.M., Wheeler W.C., Martindale M.Q., Giribet G. 2008. Broad phylogenomic sampling improves resolution of the animal tree of life // Nature. Vol.452. P.745-749.

Dautov S.Sh., Nezlin L.P. 1992. Nervous System of the Tornaria Larva (Hemichordata: Enteropneusta). A Histochemical and Ultrastructural Study // Biol. Bull. Vol.183. P.463-475.

Emig C.C. 1974. Observations et discussions sur le developpement embryonnaire des Phoronida // Z. Morph. Tiere. Vol.77. P.317-335.

Emig C.C. 1977a. Notes sur la lacalisation, l'ecologie et la taxonomie des Phoronidiens // Téthys. T.7. P.357-364.

Emig C.C. 1977b. Embriology of Phoronida// Amer. Zool. Vol.17. P.21-37.

Emig C.C., Siewing R. 1975. The Epistome of Phoronis psammophila (Phoronida)//Zool. Anz. Bd.194. No.1/ 2. S.47-54. 
Foettinger A. 1882. Note sur la formation du mesoderme dans la larve de Phoronis hippocrepia // Arch. Biol. Paris. Vol.3. P.679-686.

Franzén A., Ahlfors K. 1980. Ultrastructure of spermatids and spermatozoa in Phoronis, phylum Phoronida // J. Submic. Cytol. Vol.12. P.585-597.

Freeman G. 1991. The bases for and timing of regional specification during larval development in Phoronis // Dev. Biol. Vol.147. P.157-173.

Freeman G., Martindale M.Q. 2002. The origin of mesoderm in phoronids // Dev. Biol. Vol.252. P.301-311.

Gardiner S.L. 1978. Fine structure of the ciliated epidermis of the tentacles of Owenia fusoformis (Polychaeta, Oweniidae) // Zoomorphol. Vol.97. P.37-48.

Gilmour T.H.J. 1978. Ciliation and function of the foodcollection and waste-rejection organs of lophophorates // Can. J. Zool. Vol.56. P.2142-2155.

Giribet G. 2008. Assembling the lophotrochozoan (=spiralian) tree of life // Phil. Trans. R. Soc. B. Vol.363. P.1513-1522.

Goodrich M.A. 1903. On the body-cavites and nefridia of the Actinotrocha Larva // Quar. J. Mic. Sci. Vol.47. P.103-121.

Grobben K. 1908. Die systematische Einteilung des Tierreiches // Verhandl. Zool.-Bot. Ges. Wien. Vol.58. P.491-511.

Grobe P., Bartolomaeus T. 2007. Coelomogenesis in larvae of Phoronis ovalis and P. muelleri (Phoronida). Available from http://www.diss.fu-berlin.de/2008/81/ chapter2.pdf

Gruhl A., Grobe P., Bartolomaeus T. 2005. Fine structure of the epistome in Phoronis ovalis: Significance for the coelomic organization in Phoronida // Invert. Biol. Vol.124. P.332-343.

Hatschek B. 1888. Lehrbuch der Zoologie. Jena: Gustav Fischer.

Hausdorf B., Helmkampf M., Nesnidal M.P., Bruchhaus I. 2010. Phylogenetic relationships within the lophophorate lineages (Ectoprocta, Brachiopoda and Phoronoida) // Mol. Phylogenet. Evol. Vol.55. P.1121-1127.

Hay-Schmidt A. 1987. The ultrastructure of the protonephridium of the Actinotroch Larva (Phoronida) // Acta Zool. Vol.68. P.35-47.

Hay-Schmidt A. 1989. The nervous system of the actinotroch larva of Phoronis muelleri (Phoronida) // Zoomorphol. Vol.108. P.333-351.

Hay-Schmidt A. 1990a. Distribution of catecholamine containing, serotonin-like and neuropeptide FMRFamidelike immunoreactive neurons and processes in the nervous system of the actinotroch larva of Phoronis muelleri (Phoronida) // Cell Tiss. Res. Vol.259. P.105-118.

Hay-Schmidt A. 1990b. Catecholamine-containing, serotonin-lake and FMRFamide-like immunoreactive neurons and processes in the nervous system of the early actinotroch larva of Phoronis vancouverensis (Phoronida): distribution and development // Can. J. Zool. Vol.68. No.7. P.1525-1536.

Hejnol A. 2010. A twist in time - the evolution of spiral cleavage in the light of animal phylogeny // Integr. Compar. Biol. Vol.50. No.5. P.695-706.
Helmkampf M., Bruchhaus I., Hausdorf B. 2008. Phylogenomic analyses of lophophorates (brachiopods, phoronids and bryozoans) confirm the Lophotrochozoa concept // Proc. R. Soc. Ser.B. Vol.275. P.1927-1933.

Henry J.Q., Martindale M.Q. 1998. Conservation of the spiralian development program: Cell lineage of the nemertean Cerebratulus lacteus // Dev. Biol. Vol.201. P.253-269.

Herrmann K. 1980. The Regionation of Phoronis muelleri (Tentaculata) // Zool. Jahrb., Anat. Bd.103. No.2. S.234-249.

Herrmann K. 1986. Ontogenesis of Phoronis muelleri (Tentaculata) with a special sight for differentiation of mesoderm and phylogenesis of coelom // Zool. Jahrb., Anat. Bd.114. No.4. S.441-463.

Hyman L.H. 1940. The invertebrates: Protozoa through Ctenophora // E.J. Boell (ed.). The invertebrates. New York: McGraw-Hill. Vol.1.

Hyman L.H. 1959. Phoronida // E.J. Boell (ed.). The invertebrates. Smaller coelomate groups. New York: McGraw-Hill. Vol.5. P.228-274.

Ikeda I. 1901. Observation on the development, structure and metamorphosis of Actinotrocha // J. Coll. Sci. Imp. Univ, Tokyo. Vol.13. P.507-591.

Ikeda I. 1903. On the development of the sexual organs and their products in Phoronis // Ann. Zool. Jap. Vol.3. P.141-153.

Jagersten G. 1955. On the early phylogeny of the Metazoa. The Bilaterogastraea-theory // Zool. Bidr. Uppsala. Vol.30. P.321-354.

Kiecker C., Niehrs C. 2001. The role of prechordal mesoderm in neural patterning // Curr. Opin. Neurobiol. Vol.11. P.27-33.

Lacalli T.C. 1990. Structure and organization of the nervous system in the actinotroch larva of Phoronis vancouverensis // Phil. Trans. Roy. Soc. L. Vol.327. P.655-685.

Lacalli T.C., Gilmour T.H.J. 2001. Locomotory and feeding effectors of the tornaria larva of Balanoglossus biminiensis // Acta Zool. Vol.82. P.117-126.

Lartillot N., Le Gour M., Adoutte A. 2002a. Expression patterns of fork head and goosecoid homologues in the mollusk Patella vulgate supports the ancestry of the anterior mesentoderm across Bilateria // Dev. Gen. Evol. Vol.212. P.551-561.

Lartillot N., Lespinet O., Vervoort M., Adoutte A. 2002b. Expression pattern of Brachiury in the mollusk Patella vulgate suggests a conserved role in the establishment of the AP axis in Bilateria // Dev. Vol.129. P.14111421.

Lüter C. 2000. The origin of the coelom in Brachiopoda and its phylogenetic significance // Zoomorphol. Vol.120. P.15-28.

Malakhov V.V., Temereva E.N. 2000. Embryonic development of the phoronid Phoronis ijimai // Russ. J. Mar. Biol. Vol.26. P.412-421.

Mallatt J., Winchell C.J. 2002. Testing the new animal phylogeny: First use of combined large-subunit and small-subunit rRNA gene sequences to classify the protostomes // Mol. Biol. Evol. Vol.19. P.289-301. 
Marcus E. 1958. On the evolution of the animal phyla // Quart. Rev. Biol. Vol.33. P.24-58.

Masterman A.T. 1900. On the Diplochorda III: The early development and anatomy of Phoronis buskii// Quart. J. Microsc. Sci. Vol.43. P.375-418.

Menon K.R. 1902. Notes of Actinotrocha // Quart. J. Mic. Sci. Vol.45. P.473-484.

Nielsen C. 1987. Structure and function of metazoan ciliary bands and their phylogenetic significance // Acta Zool. Vol. 68. P.205-262.

Nielsen C., Riisgård H.U. 1998. Tentacle structure and filter-feeding in Crisia eburnea and other cyclostomatous bryozoans, with a review of upstream-collecting mechanisms // Mar. Ecol. Prog. Ser. Vol.168. P.163-186.

Paps J., Baguñà J., Riutort M. 2009. Lophotrochozoa internal phylogeny: new insights from an up-to-date analysis of nuclear ribosomal genes // Proc. R. Soc. Ser.B. Vol.276. P.245-1254.

Pennerstorfer M., Scholtz G. 2011. Spiral features of early cleavage in Phoronida // Abstracts of $2^{\text {nd }}$ International congress on invertebrate morphology. Boston, Cambridge. P.119.

Rattenbury J.S. 1953. Reproduction in Phoronopsis viridis. The annual cycle in the gonads, maturation and fertilization of the ovum // Biol. Bull. Vol.104. P.182-196.

Rattenbury J.S. 1954. The embryology of Phoronopsis viridis // J. Morphol. Vol.95. P.289-334.

Remane A. 1949. Die Entstehung der Metamerie der Wirbellosen // Verh. Dteutsch. Zool. Ges. in Mainz 1949. Zool. Anz. Suppl. Bd.42. S.16-23.

Reunov A.A., Klepal W. 2003. Ultrastructural study of spermatogenesis in Phoronopsis harmeri (Lophophorata, Phoronida) // Helgol. Mar. Res. Vol.57. P.256-260.

Riisgård H.U. 2002. Methods of ciliary filter feeding in adult Phoronis muelleri (phylum Phoronida) and its free-swimming actinotroch larva// Mar. Biol. Vol.141. P.75-87.

Roule L. 1900. Etude sur le developpement embryonnaire des Phoronidiens // Ann. Sci. Nat. Vol.11. P.51-251.

Santagata S. 2004. Larval development of Phoronis pallida (Phoronida): Implications for morphological convergence and divergence among larval body plans // J. Morphol. Vol.259. P.347-358.

Santagata S., Cohen B. 2009. Phoronid phylogenetics (Brachiopoda; Phoronata): evidence from morphological cladistics, small and large subunit rDNA sequences, and mitochondrial cox 1 // Zool. J. Linn. Soc. Vol.157. P.34-50.

Santagata S., Zimmer R.L. 2002. Comparison of the neuromuscular system among actinotroch larvae: systematic and evolutionary implication // Evol. Dev. Vol.4. P.43-54.

Scholz C.B., Technau U. 2003. The ancestral role of Brachyury: expression of NemBral in the basal cnidarians Nematostella vectensis (Anthozoa) // Dev. Genes. Evol. Vol.212. P.563-570.

Sedgwick A. 1884. On the origin of metameric segmentation and some other morphological question // Quart. J. Mic. Sci. Vol.24. P.43-82.
Seifert R., Jacob M., Jacob H.J. 1993. The avian prechordal head region: a morphological study // J. Anat. Vol.183. P.75-89.

Selys-Longchamps M. 1902. Developpement des Phoronis // Arch. Biol. T.18. P.495-597.

Selys-Longchamps M. 1907. Phoronis. Fauna und Flora des Golfes von Neapel. Monogr. 30. 280 S.

Siewing R. 1980. Das Archicoelomatenkonzept // Zool. Jahrb, Anat. Ontog. Bd.103. S.439-482.

Shearer C. 1906. Studies on the development of larval nephridia. Part 1. Phoronis // Mitt. Zool. Station Neapel. Vol.17. P.487-514.

Smart T., von Dasssow G., 2009. Unusual development of the mitraria larva in the Polychaete Owenia collaris // Biol. Bull. Vol.217. P.253-268.

Smith P.R., Ruppert E.E. 1988. Nephridia // W. Westheide, C.O. Hermans (ed.). The Ultrastructure of the Polychaeta. Microfauna Marine. Stuttgart: G. Fisher. Vol.4. P.231-262.

Strathmann R.R. 2006.Versatile ciliary behaviour in capture of particles by the bryozoan cyphonautes larva // Acta Zool. Vol.87. P.83-89.

Strathmann R.R., Bonar D. 1976. Ciliary feeding of tornaria larvae of Ptychodera flava (Hemichordata: Enteropneusta) // Mar. Biol. Vol.34. P.505-519.

Strathmann R.R., Bone Q. 1997. Ciliary feeding assisted by suction from the muscular oral hood of phoronid larvae // Biol. Bull. Vol.193. P.153-162.

Strathmann R.R., MacEdward L.R. 1986. Cyphonautes ciliary sieve breaks a biological rule of inference // Biol. Bull. Vol.171. P.754-760.

Tagawa K., Satoh N., Humpreys T. 2001. Molecular studies of hemichordate development: a key to understanding the evolution of bilaterian animals and chordate // Evol. Dev. Vol.3. P.443-454.

Technau U. 2001. Brachiury, the blastopore and evolution of the mesoderm // Bioessays. Vol.23. P.788-794.

Takade N., Goto T., Satoh N. 2002. Expression pattern of the Brachiury gene in the arrow worm Paraspadella gotoi (Chaetognatha) // Genesis. Vol.32. P.240-245.

Technau U., Bode H.R. 2001. Brachiury homologue, acts during head formation in Hydra // Dev. Vol.126. P.999-1010.

Temereva E.N. 2010. The digestive tract of actinotroch larvae (Lophotrochozoa, Phoronida): anatomy, ultrastructure, innervations, and some observations of metamorphosis // Can. J. Zool. Vol.88. No.12. P.11491168.

Temereva E.N. 2012. Ventral nerve cord in Phoronopsis harmeri larvae // J. Exp. Zool. (Mol. Dev. Evol.). Vol.318. P.26-34.

Temereva E.N., Malakhov V.V. 2000. The circulatory system of phoronid larvae// Doklady Biol. Sci. Vol.375. No.5. P.712-714.

Temereva E.N., Malakhov V.V. 2006a. The answer to Thomas Bartolomaeus: "Larva of phoronid Phoronopsis harmeri Pixell, 1912 has trimeric coelom organization" // Invert. Zool. Vol.2. No.2. P.394-402.

Temereva E.N., Malakhov V.V. 2006b. Microscopical anatomy and ultrastructure of the lophophoral organs 
and adjacent epitheliums of the lophophoral concavity and anal papilla of Phoronopsis harmeri Pixell, 1912 (Lophophorata, Phoronida) // Russ. J. Mar. Biol. Vol.32. No.3. P.134-141.

Temereva E.N., Malakhov V.V. 2006c. Development of the excretory organs of the Phoronopsis harmeri (Phoronida): from protonephridium to nephromixium // Entomol. Rev. Vol.86. Suppl. 2. P.201-209.

Temereva E.N., Malakhov V.V. 2007. Embryogenesis and larval development of Phoronopsis harmeri Pixell, 1912 (Phoronida): Dual origin of the coelomic mesoderm // Invert. Reprod. Dev. Vol.50. P.5766.

Temereva E.N., Malakhov V.V. 2009. [The development of phoronids] // Zapiski Kazanskogo Universiteta. Vol.151. No.2. P.8-33 [in Russian].

Temereva E.N., Malakhov V.V. 2011a. Organization of the epistome in Phoronopsis harmeri (Phoronida) and consideration of the coelomic organization in Phoronida // Zoomorphol. Vol.130. P.121-134.

Temereva E.N., Malakhov V.V. 2011b. The evidence of metamery in adult brachiopods and phoronids // Invert. Zool. Vol. 8. No.2. P.87-101.

Temereva E.N., Malakhov V.V., Yushin V.V. 2011. Ultrastructural study of oogenesis in the phoronid Phoronop- sis harmeri (Phoronida) // Acta Zool. Vol.92. P.241250.

Weygoldt P. 1960. Embryologische Untersuchungen an Ostracoden: Die Entwicklung von Cyprideis litoralis // Zool. Jahrb., Anat. Bd.78. S.370-426.

Weygoldt P. 1961. Beitrag zur Kenntnis der Ontogenie der Decapoden: embryologische Untersuchungen an Palaemonetes varians (Lach.) // Zool. Jahrb., Anat. Bd.79. S.223-294.

Zimmer R.L. 1967. The morphology and function of accessory reproductive glands in the lophophores of Phoronis vancouverensis and Phoronopsis harmeri // J. Morphol. Vol.121. P.116-121.

Zimmer R.L. 1973. Morphological and developmental affinities of the lophophoratesn // G.P. Larwood (ed.). Living and fossil Bryozoa. Recent Advances in Research. New York: Academic Press. P.593-599.

Zimmer R.L. 1980. Mesoderm proliferation and formation of the protocoel and metacoel in early embryos of Phoronis vancouverensis (Phoronida) // Zool. Jahrb., Anat. Bd.103. No.2. S.219-233.

Responsible editors E.V. Bogomolova, K.G. Mikhailov 